University of Pittsburgh School of Law

Scholarship@PITT LAW

1998

\title{
Light on a Darkling Plain: Intercircuit Conflicts in the Perspective of Time and Experience
}

Arthur D. Hellman

University of Pittsburgh School of Law, hellman@pitt.edu

Follow this and additional works at: https://scholarship.law.pitt.edu/fac_articles

Part of the Jurisprudence Commons, Public Law and Legal Theory Commons, and the Supreme Court of the United States Commons

\section{Recommended Citation}

Arthur D. Hellman, Light on a Darkling Plain: Intercircuit Conflicts in the Perspective of Time and Experience, 1998 The Supreme Court Review 247 (1998).

Available at: https://scholarship.law.pitt.edu/fac_articles/365

This Article is brought to you for free and open access by the Faculty Publications at Scholarship@PITT LAW. It has been accepted for inclusion in Articles by an authorized administrator of Scholarship@PITT LAW. For more information, please contact leers@pitt.edu, shephard@pitt.edu. 


\title{
Light on a Darkling Plain: Intercircuit Conflicts in the Perspective of Time and Experience
}

\author{
Arthur D. Hellman
}

\begin{abstract}
The time has long passed when the Supreme Court resolved every intercircuit conflict properly brought before it in a petition for certiorari. Is that a problem we should be concerned about? Three decades ago, Congress asked the Federal Judicial Center, the research arm of the federal judiciary, to conduct a study to ascertain "the number and frequency of conflicts among the judicial circuits ... that remain unresolved because they are not heard by the Supreme Court." Congress further requested that the Center determine the extent to which the unresolved conflicts are "intolerable." The Center asked me to design and conduct the study. The study found that although the number of unresolved conflicts was larger than previous studies had suggested, the numbers alone gave a distorted picture of the phenomenon. Most of the conflicts that the Supreme Court does not hear either do not generate any of the consequences that might make them "intolerable" or do so only for a short period of time.

Subsequently, I undertook another empirical study of unresolved intercircuit conflicts. It contained two elements. First, I investigated the later history of the conflicts identified in the initial project. Second and more ambitiously, I carried out a unique program of field research that included individual and group interviews of attorneys, examination of continuing legal education materials, and an in-depth survey of members of two specialty bars.

This article reports the results of this later research. The principal conclusion is that the problem of unresolved conflicts exists only if you look for it -and look for it in a certain way. If you concentrate your attention on individual court of appeals decisions that create conflicts and on individual denials of certiorari in conflict cases, you will see (in the words of Chief Justice Rehnquist) "a judicial 'darkling plain' where ignorant armies [clash] by night." But if you look at the conflict issues over a period of time and in context, you will find, if not certitude, a landscape in which courts build upon and reexamine one another's decisions in the untidy but constructive tradition of the common law..

The field research also suggests a broader point. The very language that we use to talk about conflicts may convey a misleading picture of what is going on. We say that an "issue" gives rise to a "conflict" that the Supreme Court "resolves" (or does not "resolve"). This language implies that the dimensions of the "issue" remain unchanged from the first decision through consideration by two or more courts of appeals and ultimate resolution by the Supreme Court. The implication is probably correct when the issue is binary and discrete - for example, the "Cartwright issue" (whether mutual fund shares in a decedent's estate are to be valued at the bid price or the asked price). For
\end{abstract}


other issues, however, the reality will not be so straightforward. Judges and lawyers may continue to frame the issue in the same words, but beneath the verbal identity may lie important differences in the propositions that are accepted as part of the legal landscape and those that are viewed as litigable. Similarly, when the Supreme Court does intervene, its decision may end up reshaping the framework for litigation and counseling about an issue rather than closing a chapter in the particular area of the law.

This pattern can be viewed as a departure from the traditional model of lawmaking by appellate courts. In that model, as memorably described by Lord Mansfield, the law "works itself pure from case to case." In the situation I have just outlined, the law never "works itself pure;" rather, uncertain boundaries and gray areas characterize the legal landscape as long the issue, in some form, remains alive. 
One of the lesser-known rituals of the Supreme Court of the United States is the annual appearance by two of the Justices at hearings of the appropriations committees of the House and the Senate. The legislators generally do not have much to say about the Court's budget, so the discussion often turns to other aspects of the Court's operations. A few years ago, a meniber of the House subcommittee asked about the dramatic decrease in the number of cases heard and decided by the Court. Justice Anthony M. Kennedy acknowledged the phenomenon and made clear that he viewed it as a healthy development. He told the subcommittee, "We are a Court that is constituted and committed to give doctrinal guidance to the judicial system as a whole. To the extent that we can do that in 100 cases rather than 140 cases we are fulfilling that function."1 Justice David Souter agreed with Justice Kennedy's assessment. ${ }^{2}$

Arthur D. Hellman is Professor of Law, University of Pittsburgh School of Law. The studies reported in this article were carried out, in large part, under a contract with the Federal Judicial Center. However, the views expressed are those of the author; the Center speaks only through its Board. Throughout the project, Judith McKenna of the Center's Research Division provided invaluable counsel. Three graduates of the University of Pittsburgh School of Law-David Gray, Benjamin Hinerfeld, and Michael Wagner-helped in important ways with the field research reported in Part III.

' Departments of Commerce, Justice, and State, the Judiciary, and Related Agencies Appropriations for 1997: Hearings Before a Subcommittee of the House Committee on Appropriations, 104th Cong, 2d Sess, Pt 6 at 23 (1996).

${ }^{2}$ Id at 24.

() 1999 by The University of Chicago. All rights reserved.

0-226-36316-3/99/1998-0003\$02.00 
The Justices' comments stand in stark contrast to the picture painted by two Congressionally created study groups. In the mid1970s, the Commission on Revision of the Federal Court Appellate System (Hruska Commission) identified what it believed to be a serious problem, the "failure of the federal judicial system to provide adequate capacity for the declaration of national law." The Commission placed particular emphasis on one consequence of this failure: the existence of conflicts between federal judicial circuits that the Supreme Court did not resolve. In 1990, another blue-ribbon group, the Federal Courts Study Committee, expressed similar concerns about the capacity of the federal judicial system to provide a uniform construction of federal law where uniformity is needed. ${ }^{4}$ The Study Committee urged Congress to authorize a pilot project under which the Supreme Court could refer selected conflict cases to a randomly chosen court of appeals for resolution.

What happened to the problem of unresolved intercircuit conflicts? Certainly there has been no amelioration in the conditions that led the Hruska Commission and the Federal Courts Study Committee to their conclusions. With one minor exception, Congress has taken no steps to expand the capacity of the system to resolve issues at the national level. ${ }^{5}$ It did not establish a National Court of Appeals as the Hruska Commission recommended, nor did it authorize the pilot project suggested by the Study Committee. The Supreme Court, as already noted, has actually reduced the number of cases that it hears and decides on the merits. ${ }^{6}$ Meanwhile, the volume of adjudications in the courts of appeals has continued to burgeon.?

The explanation, I suggest, is that the Hruska Commission and

\footnotetext{
${ }^{3}$ Commission on Revision of the Federal Court Appellate System, Structure and Internal Procedures: Recommendations for Change, 67 FRD 195, 217 (1975) (hereafter Hruska Commission Report). I served as Deputy Director of the Commission and helped to write its report.

${ }^{4}$ Federal Courts Study Committee, Report of the Federal Courts Study Committee 125 (1990) (hereafter Study Committee Report).

${ }^{5}$ In 1982, Congress established the Court of Appeals for the Federal Circuit and gave it exclusive jurisdiction over appeals in certain classes of cases, notably those involving patents. See generally Rochelle Dreyfuss, The Federal Circuit: A Case Study in Specialized Courts, 64 NYU L Rev 1 (1989).

'See Arthur D. Hellman, The Shrunken Docket of the Rebnquist Court, 1996 Supreme Court Review 403 (1997).

' See Richard A. Posner, The Federal Courts: Challenge and Reform 53-64 (Harvard, 1996).
} 
the Study Committee, like others who have viewed unresolved conflicts as a major problem, have looked at the legal landscape from an unduly narrow perspective. They have counted the number of conflicts in existence at a particular moment in time without asking what happens to those conflicts over a span of years and without considering the significance of the conflicts-in particular, their effect on outcomes. In an article published in 1995, I took the first step toward providing that broader perspective. I presented the results of an empirical study of conflicts that the Supreme Court did not resolve. ${ }^{8}$ The study paid particular attention to the tolerability and persistence of the conflicts. It concluded that unresolved intercircuit conflicts do not constitute a problem of serious magnitude in the federal judicial system.

Of course, no single study can be definitive, especially when the subject involves the operation of precedent in a common-law system. Moreover, not everyone agrees with the conclusion. The chairman of the Federal Courts Study Committee has lamented that "only a small number of the ever increasing disparate decisions by the courts of appeals can be reconciled by the Supreme Court. Practically speaking, this means that litigants in various parts of the country are governed by federal case law that differs from circuit to circuit." Professor Thomas Baker insists that "some conflicts are going unresolved and that they are accumulating faster than the system is correcting [them]." 10

To supplement the research reported in the 1995 article, I have pursued two additional lines of empirical inquiry. First, I have investigated the later history of a group of unresolved conflicts identified in the earlier study. Second, I have carried out a program of field research to determine the actual effect of unresolved conflicts on the practice of law. The results of the new studies are reported in this article. Before turning to the new data, I provide some background, including a brief summary of the initial study.

\footnotetext{
${ }^{8}$ Arthur D. Hellman, By Precedent Unbound: The Nature and Extent of Unresolved Intercircuit Conficts, 56 U Pitt L Rev 693 (1995) (hereafter Hellman, By Precedent Unbound).

${ }^{9}$ Statement of Joseph F. Weis, Jr., before tbe Commission on Structural Alternatives for the Federal Courts of Appeals, New York, April 24, 1998. At the time this article was prepared, Judge Weis's statement was available on-line at the Commission's website, http:// app.comm.uscourts.gov.

${ }^{10}$ Thomas E. Baker, The U.S. Courts of Appeals: Problems and Solutions, Federal Lawyer (August 1998) at 31, 32.
} 


\section{BACKGROUND}

Concern about the adequacy of the "national appellate capacity" "can be traced at least as far back as 1968, when a committee of the American Bar Foundation warned that "the function of the Supreme Court as an agency for harmonizing and unifying federal law is spread ever more thinly." 12 Over the next two decades, similar themes were sounded by prominent scholars and jurists as well as by the Hruska Commission. ${ }^{13}$ In 1990, the Federal Courts Study Committee recommended a more focused study to complement its proposed "pilot project." 14 Congress acted on that recommendation in Section 302 of the Judicial Improvements Act of 1990. In Section 302, Congress asked the Federal Judicial Center, the research arm of the federal judiciary, to conduct a study to ascertain "the number and frequency of conflicts among the judicial circuits ... that remain unresolved because they are not heard by the Supreme Court." ${ }^{15}$ Congress further requested that the Center determine the extent to which the unresolved conflicts are "intolerable." The Center asked me to design and conduct the study.

\section{A. IDENTIFYING CONFLICTS}

Scholars, judges, and lawyers have disagreed for more than half a century over what constitutes an intercircuit conflict. ${ }^{16}$ In Section 302 , Congress framed the inquiry in a way that made it largely unnecessary to rely on any abstract definition. The statutory language suggested that the task of assessing the consequences of conflicts-and thus their tolerability - should be separated from the determination whether a conflict exists. The legislative history called for a study that would provide, to the extent possible, objec-

\footnotetext{
${ }^{11}$ See Hruska Commission Report at 246 (cited in note 3).

${ }^{12}$ American Bar Foundation, Accommodating the Workload of the United States Courts of Appeals 6 (1968).

${ }^{13}$ See, for example, Paul M. Bator, What Is Wrong With the Supreme Court? 51 U Pitt L Rev 673 (1990) (lecture delivered in 1987).

${ }^{14}$ Study Committee Report at 125 (cited in note 4).

${ }^{15}$ Pub L No 101-650, $\$ 302,104$ Stat 5089, 5104 (1990).

${ }^{16}$ See, for example, Felix Frankfurter and Henry M. Hart, Jr., The Business of the Supreme Court at October Term, 1933, 48 Harv L Rev 238, 268 (1934).
} 
tive data. These themes shaped the methods I adopted and the criteria I used.

The study was carried out in two phases. In the first phase, I analyzed two sets of cases that the Supreme Court declined to hear. The first group included all cases in the 1988, 1989, and 1990 Terms in which Justice Byron White dissented from the denial of certiorari. This set of cases was chosen as the starting point because, over the years, Justice White repeatedly called attention to the Court's failure to resolve intercircuit disagreements. ${ }^{17}$ The "Dissent Group," as I called it, included 237 cases. The second group was a random sample drawn from the 1989 Term. The sample encompassed one of every five paid cases denied review in that Term after the filing of a brief in opposition. The "Random Group" consisted of 253 cases.

To determine whether a Study Group case involved a conflict between circuits, I followed an approach that was essentially reportorial. I began by asking whether a claim of conflict was presented in the certiorari petition and other materials submitted by the parties. If it was, I examined the allegedly conflicting decisions to ascertain if the disagreement was acknowledged by one or more of the courts of appeals that had decided the issue. Acknowledged conflicts were included in the tally without any attempt to determine whether the conflict was "genuine." If the conflict was not acknowledged, I proceeded with research to discover whether the assertion of conflict was supported by writings of judges, commentators, or other participants in the legal system. Recognized conflicts were also included in the tally without independent analysis. Only when all of these sources proved unavailing did I undertake my own assessment of whether the decisions were truly in conflict.

Using these techniques, I found 166 substantiated claims of conflict among Justice White's dissents: 38 in the 1988 Term, 59 in 1989 , and 69 in 1990 . All but 11 of the 166 were either acknowledged by a court of appeals or recognized by other participants in the system. Applying the same criteria to the paid cases in the Random Group, I found 44 conflicts, all but two of which were acknowledged or recognized.

\footnotetext{
${ }^{17}$ Justice White retired at the end of the 1992 Term, and no Justice has taken his place in publicly calling attention to conflict cases. Thus the method of the study could not be replicated today.
} 
These data answered the first of the questions posed by Congress. The number of intercircuit conflicts that are not heard by the Supreme Court is large enough that the existence of a problem of "inadequate national capacity" could not be ruled out on the basis of raw numbers alone. But that finding only set the stage for the next level of inquiry: investigating the "tolerability" of the unresolved conflicts.

\section{B. ASSESSING TOLERABILITY}

"Tolerability" is a shorthand for the effect of conflicts on litigation, counseling, and primary activity. The Federal Courts Study Committee identified four consequences that would tend to make a conflict intolerable: nonacquiescence by federal government agencies, harm to multicircuit actors, forum shopping among circuits, and unfairness to litigants in different regions of the country. ${ }^{18}$ To assess the tolerability of the Phase I conflicts, I began by identifying objectively defined characteristics that are likely to correlate with one or more of these consequences. I then built upon that framework to analyze the conflicts in the Study Group. The findings were quite striking.

The first of the consequences identified by the Study Committee-nonacquiescence-can virtually be ruled out as an element of intolerability. The essence of the evil, as the Study Committee viewed it, is that federal administrative agencies are forced to choose "between the uniform administration of statutory schemes and obedience to the different holdings of courts in different regions." 19 But examination of the Study Group cases reveals that there is almost no overlap between nonacquiescence and unresolved intercircuit conflicts. ${ }^{20}$ Nonacquiescence may be a problem in the legal system, but it is not a problem that results from the Supreme Court's failure to resolve the conflicts that are brought to it.

A second of the Study Committee's factors-forum shopping among circuits-can be put to one side for a different reason. Upon analysis, forum shopping between circuits proves to be an

\footnotetext{
${ }^{18}$ See Study Committee Report at 125 (cited in note 4).

${ }^{19} \mathrm{Id}$.

${ }^{20}$ See Hellman, By Precedent Unbound at 742-48 (cited in note 8).
} 
evil only to the extent that it threatens harm to multicircuit actors or causes unfairness to litigants in different regions. ${ }^{21}$ Intolerability thus depends entirely on the latter two factors.

The possibility of inflicting harm on multicircuit actors, I concluded, depends in the first instance on the subject matter of the conflict and the nature of the issues. On the basis of those variables alone, the research tells us that a substantial majority of the unresolved conflicts would have no impact on the legal position of entities whose activities cross circuit lines. ${ }^{22}$ Included here are almost all conflicts in several important categories of federal law: the constitutional rights of criminal defendants, the elements of typical federal crimes, the interpretation of 42 USC $\$ 1983$, and the availability of federal habeas corpus for state prisoners. Thus, under the approach suggested by the Study Committee, these conflicts would be deemed intolerable only to the extent that they give rise to unfairness to litigants in different circuits.

In giving content to the concept of "unfairness," I drew upon the insights of scholars and judges in two analogous contexts: the Erie doctrine ${ }^{23}$ and retroactivity. ${ }^{24}$ I concluded that unfairness to litigants in different circuits, like the other consequences that concerned the Study Committee, depends primarily on the extent to which the difference in circuit law produces divergent outcomes in similar cases. From this perspective, the conflicts could be divided into three broad groupings: those that are outcome-determinative, those that produce systematic bias, and those that do not generate either of those consequences.

A conflict is classified as outcome-determinative if the choice of rule can be expected to control the resolution of a claim or defense in all cases in which the issue arises, or in any class of cases that can be identified ex ante. Because most legal rules contain elements of indeterminacy or are tempered in their operation by other rules, only a small proportion of the conflicts fit this pattern. More commonly, conflicts fall into the intermediate grouping: the choice of

\footnotetext{
${ }^{21}$ Id at $754-56$.

${ }^{22}$ Id at $748-51$.

${ }^{23}$ See generally John Hart Ely, The Irrepressible Myth of Erie, 87 Harv L Rev 693, 712 17 (1974).

${ }^{24}$ Particularly helpful was the opinion of Judge Posner in Luddington $v$ Indiana Bell Tel. Co., 966 F2d 225, 228 (7th Cir 1992).
} 
rule will not lead to divergent outcomes in an identifiable class of cases, but it can be expected to bias decision systematically in favor of one side in a recurring class of disputes. ${ }^{25}$

A strong argument can be made that systematic bias differs in degree but not in kind from the indeterminacy that is inherent in common law adjudication. If one accepts this view, analysis of the Phase I cases establishes that a majority of unresolved conflictsindeed, probably a substantial majority-will not generate any of the consequences that would put them in the realm of the "intolerable."

\section{INVESTIGATING PERSistenCE}

At this point I had taken objective analysis based on the Study Committee factors as far as it could go. But that did not mean that I had to abandon efforts to evaluate the significance of unresolved conflicts. Although the Study Committee did not develop the point, it implicitly recognized that conflicts have a temporal dimension. ${ }^{26}$ Further, my own prior research provided numerous instances of conflicts that were denied review in one Supreme Court Term but resolved in a subsequent Term when brought to the Court by another petitioner. I therefore undertook an investigation of the persistence of unresolved conflicts.

Persistence in the broad sense can be viewed as an element of tolerability; the difference lies in the temporal perspective. In analyzing the tolerability of the Phase I conflicts, I took as a given the landscape of the law at the time the Supreme Court denied review. A study of persistence, on the other hand, concentrates on what happens to the conflicts that the Court does not hear. Do they "remain unresolved" for long periods of time? Does the Court step in when the same issue is presented in another case? Or do the conflicts disappear or become irrelevant without a Supreme Court decision?

The cases studied in Phase I could provide only limited insights into the persistence of unresolved conflicts because the denials of

\footnotetext{
${ }^{25}$ For elaboration and examples, see Hellman, By Precedent Unbound at 765-69 (cited in note 8 ).

${ }^{26}$ See Study Committee Report at 125 (cited in note 4) (emphasizing importance of providing a "nationally binding construction" of statutes "within a reasonable time").
} 
certiorari were so recent. Thus, to pursue this line of inquiry, it was necessary to investigate the fate of conflicts denied review in earlier years. To that end, in Phase II of the study I went back to the 1984 and 1985 Terms of the Supreme Court and traced the subsequent history of 142 conflicts that were "not heard" by the Court during that period. I selected that period because a compilation of conflicts was available as part of an unpublished study conducted at the request of Chief Justice Burger.

After analyzing court rulings and secondary sources, I found fewer than 40 conflicts out of the 142 that $(a)$ had not been put to rest by a Supreme Court decision or otherwise, $(b)$ continued to generate litigation, and $(c)$ controlled outcomes in one or more reported cases. Of these, perhaps a dozen had some potential for encouraging nonacquiescence or causing harm to multicircuit actors; the remainder implicated only the "unfairness" factor. In short, the research indicated that most of the conflicts the Supreme Court does not hear either do not generate the consequences that concerned the Study Committee or do so only for a short period of time.

In reliance on the research conducted in Phase I and Phase II, the long-range planning committee of the Judicial Conference of the United States recommended that " $[t]$ he United States Supreme Court should continue to be the sole arbiter of conflicting precedents among the courts of appeals." 27 That recommendation was endorsed by the Conference itself. ${ }^{28}$ But not everyone agrees that unresolved conflicts are not a cause for worry. I have already quoted observations by Judge Weis and Professor Baker $;{ }^{29}$ former Solicitor General Kenneth W. Starr has spoken in a similar vein. ${ }^{30}$ Thus it is appropriate to pursue new lines of inquiry to determine whether the complacency of Justice Kennedy and Justice Souter is warranted.

\footnotetext{
${ }^{27}$ Committee on Long Range Planning [of the] Judicial Conference of the United States, Proposed Long Range Plan for the Federal Courts 43 (Recommendation 20) (1995).

${ }^{28}$ Judicial Conference of the United States, Long Range Plan for the Federal Courts 46 (Recommendation 19) (1995). The Judicial Conference and its committee based their conclusion on the Draft Final Report on the research. See id at $\mathrm{n} 10$.

${ }^{29}$ See notes 9-10 and accompanying text.

${ }^{30}$ Kenneth W. Starr, The Supreme Court and the Federal Fudicial System, 42 Case Western L Rev 1209, 1212 (1992).
} 


\section{The Later History of the Phase I Conflicts}

In the study cited by the Judicial Conference and its longrange planning committee, I analyzed the tolerability of the substantiated conflicts in the Phase I Study Group and the persistence of the substantiated conflicts in the Phase II Study Group. Because the denial of certiorari in the Phase I cases was still recent, I had only fragmentary information about the later history of those issues. With the passage of time, however, it became possible to investigate the persistence of the Phase I conflicts. Although resources did not permit research on the comprehensive scale of the initial enterprise, I was able to trace and analyze later developments in sufficient depth to answer the basic questions: How many of the conflicts remain alive? To what extent are they likely to give rise to the consequences that make for intolerability?

As explained in the preceding section, the Phase I Study Group encompassed two sets of cases that the Supreme Court declined to hear. The first group included all cases in the 1988, 1989, and 1990 Terms in which Justice White dissented from denial of certiorari. That group gave us a total of 166 substantiated conflicts. The second group was a random sample drawn from the 1989 Term. That sample ultimately yielded a total of 44 substantiated conflicts. Nine conflicts appeared twice in the Study Group: five cases in the Dissent Group also turned up in the random sample, and four conflicts from the random sample prompted a dissent by Justice White in a different case. Thus, for the follow-up study, I investigated the later history of 201 conflicts that were denied review in the Supreme Court's 1988, 1989, and 1990 Terms. ${ }^{31}$ The bulk of the work was carried out in late 1997 and early 1998, with some additional research in early fall of 1998. The analysis reflects all Supreme Court action through the end of the 1997-98 Term. ${ }^{32}$

The new research strongly reinforces the conclusion set forth in the earlier article. Of the 201 conflicts, 62 have been put to rest by legislative or judicial action. Another 63 conflicts have died a natural death; either the underlying issue has disappeared or there

\footnotetext{
${ }^{31}$ In reporting the findings, I shall use "case" and "conflict" interchangeably.

${ }^{32}$ Detailed write-ups on the individual cases are on file with the author and with the Federal Judicial Center. Cases discussed in this article are identified by record number (“RN").
} 
is no longer any evidence of intercircuit disagreement. Among the conflicts that have not been put to rest, there are no more than 50 that manifest characteristics that contribute to intolerability.

In addition to the findings, the new research further refines the analytical framework. It is now clear that a conflict can "evaporate" even though the issue remains alive at a some higher level of generality. For conflicts that cannot be said to have evaporated, a critical question is whether any later court has found it necessary to reject a precedent from another circuit.

\section{A. CONFLICTS PUT TO REST}

Shortly after Justice White retired from the Supreme Court, Justice Antonin Scalia offered an explanation of why the Court so often rejects a certiorari petition notwithstanding the presence of an intercircuit conflict. In remarks to a group of judges and lawyers, Justice Scalia suggested that "in many . . . , perhaps most of the cases that Justice White used to write about," the Court did not deny certiorari because "the rest of us didn't think the conflict was significant enough"; rather, the Court denied certiorari because "there was the problem of a threshold question that you would have to overcome in order to reach the question that you're interested in." 33 Justice Scalia added pointedly: "If it's really an important issue, it's going to be back next term; it may be back later this term." 34

The findings of this study provide some support for Justice Scalia's assessment. Of the 201 conflicts in the Study Group, 45 were resolved when the Supreme Court granted review in a later case. Thirty-two decisions explicitly addressed the issue on which courts of appeals disagreed. Generally the Court's opinion specified the conflict as the reason for granting review and cited one or more of the appellate rulings that were brought to the Court's attention in the earlier petition. Another 13 conflicts were implic-

\footnotetext{
${ }^{33}$ Proceedings of the Fifty-Fifth Judicial Conference of the District of Columhia Circuit, I60 FRD I69, 2 I5 (I994) (remarks of Justice Scalia).

${ }^{34} \mathrm{Id}$. Chief Justice Rehnquist pointed to another reason why the Court denied review in some of the conflict cases flagged by Justice White: the rule rejected by the court below was less favorable to the petitioner than the competing rule, so that the petitioner "would lose whichever of these rules is adopted." Id at 216 (remarks of Chief Justice Rehnquist). That too would lead the Court to wait for another case "next term [or] later this term."
} 
itly resolved when the Supreme Court decided a case involving a closely related question. ${ }^{35}$

Although Justice Scalia did not mention it, the Supreme Court is not the only institution that has the power to end litigation over a conflict issue. Legislative bodies can change the law, and courts of appeals can change their minds. Among the Study Group conflicts, 10 have been mooted through some kind of legislative action-Acts of Congress, amendments to the Sentencing Guidelines, or revisions to procedural rules. Seven conflicts were eliminated when the minority circuit overruled the nonconforming decision. In all, 62 conflicts had been put to rest by judicial or legislative action when the Court's 1997 Term ended in June 1998.

If no judicial or legislative body has taken action to put a conflict to rest, does that mean that the conflict remains alive? Not necessarily. On the contrary, one of the major findings of this research is that conflicts can die without any directed or self-conscious intervention by a judicial or legislative body. There are two distinct ways in which this can happen. One is quite straightforward; the other is somewhat more subtle.

In 35 cases, the conflict died a natural death through what can be described as "burial" of the underlying issue. ${ }^{36}$ Some of the issues never generated a reported decision after the denial of certiorari. Half a dozen hung on until early 1994 (or in one instance late 1994). The remaining issues disappeared from sight sometime during the early 1990s.

I recognize, of course, that reported decisions do not necessarily reflect the universe of lawsuits or the realities of legal practice. However, with one or two exceptions, I am confident that the issues I have classified as "buried" have little prospect for revival. Further, many of the now-dead conflicts were quite attenuated to begin with. Even if the issues were to reappear in some form, the likelihood is small that they would entail any of the consequences that make for intolerability.

In 28 cases, the issue remained alive to a greater or lesser degree;

\footnotetext{
${ }^{35}$ An example is the conflict over the availability of punitive damages for injuries suffered by seamen. For discussion, see Part IV.

${ }^{36}$ See Darr v Burford, 339 US 200, 227 (Frankfurter, J, concurring) (noting that the passage of time may "bury [a] question.").
} 
however, the conflict presented to the Supreme Court has evaporated. This is a phenomenon that I have not previously identified. "Evaporation" refers to the situation in which courts continue to cite precedents on one or both sides of a once-live conflict, but there is no recent evidence that any court has seen a need to choose between precedents or that the law differs from one circuit to another.

The phenomenon is illustrated, rather surprisingly, by a case in the Random Group. In Berda $v$ CBS Inc., ${ }^{37}$ the Third Circuit confronted what the court described as "a circuit-splitting question: whether state contract and tort claims for monetary relief brought by a bargaining unit employee against his employer based upon alleged misrepresentations of job security, made before the employee became a member of the bargaining unit, ... are preempted by $\$ 301$ of the LMRA [Labor-Management Relations Act]." 38 The court held that the plaintiff's claims were not preempted; it noted that the Ninth Circuit had reached a different result on "similar facts" in Bale $v$ General Telephone Co. ${ }^{39}$ Notwithstanding the acknowledged disagreement, the Supreme Court denied certiorari. Litigation continued, and in the early 1990s the conflict appeared to be one of the most acute in the Random Group. ${ }^{40}$

Today the picture looks very different. A recent commentator, surveying decisions in all circuits over a period of nearly 10 years, found that "virtually every lower federal court considering the issue has held that pre-collective bargaining agreement assurances of job security are not preempted by section 301." 41 The Ninth Circuit, which might have been viewed as an outlier, has distinguished Bale and held that a claim for negligent misrepresentation was not preempted. ${ }^{42}$ To be sure, there remains more than a little uncertainty about the scope of Section 301 preemption in other

${ }^{37} 881$ F2d 20 (3d Cir 1989), cert denied, 493 US 1062 (1990) (RN 335).

${ }^{38}$ Id at 20.

${ }^{39} 795$ F2d 775 (1986).

${ }^{40}$ The issue was again presented to the Court in the 1991 Term. See White $v$ National Steel Corp., 938 F2d 474 (4th Cir), cert denied, 502 US 974 (1991). This time Justice White dissented from the denial of certiorari.

${ }^{41}$ Richard A. Bales, The Discord Between Collective Bargaining and Individual Employment Rights: Theoretical Origins and a Proposed Reconciliation, 77 BU L Rev 687, 760 n 147 (1997).

${ }^{42}$ See Beals $v$ Kiewit Pacific Co., 114 F3d 892, 895 (9th Cir 1997). 
contexts. ${ }^{43}$ But no court in several years has had to choose between circuit positions on the issue presented in Berda-preemption of claims involving pre-hire misrepresentations of job security-and no court has acknowledged or recognized any intercircuit disagreement. The conflict is no more.

I have recounted this history to show how a conflict that once loomed large can lose all potency, not to suggest that Berda is typical of the conflicts that have evaporated. It is not. Few of the conflicts in this category are associated with a broader issue that remains unsettled. Many had little substance even at the time certiorari was denied in the Study Group case. Some of the underlying issues are all but buried. The details vary; what is clear in each of the cases is that there is no longer a disgreement that leads to divergent outcomes depending on the circuit where a dispute is litigated.

\section{B. CONFLICTS NOT PUT TO REST}

The analysis thus far accounts for all but 76 of the conflicts in the Phase I Study Group. These are the conflicts that cannot be deemed to have been put to rest. But the fact that a conflict remains alive is not necessarily cause for concern. Rather, we must ask whether the continued existence of the conflict has generated one or more of the consequences that the Federal Courts Study Committee identified as contributing to intolerability.

In my earlier analysis, I suggested that the key to intolerability is effect on outcomes. As explained in the account of the Phase II Study Group, "Unless the choice between the competing rules leads courts to reach divergent results in similar cases, none of the consequences that concerned the Study Committee are likely to materialize." 44 I adhere to that view, but, in light of the limited resources available for research in this phase, I looked for another benchmark that would more readily identify those conflicts that have truly made a difference. I found it in the course of working on a related project. ${ }^{45}$ A strong signal that a conflict leads to divergent

\footnotetext{
${ }^{43}$ The Supreme Court itself has said that "the Courts of Appeals have not been entirely uniform in their understanding and application of the principles set down in [two Supreme Court decisions]." Livadas v Bradshaw, 512 US 107, 124 n 18 (1994).

${ }^{44}$ Hellman, By Precedent Unbound at 785 (cited in note 8).

${ }^{45}$ See Arthur D. Hellman, Precedent, Predictability, and Federal Appellate Structure, $60 \mathrm{U}$ Pitt L Rev (forthcoming I999).
} 
outcomes is the rejection by a court in one circuit of another circuit's precedent. ${ }^{46}$ Applying this new framework and examining decisions over the last four years, ${ }^{47} \mathrm{I}$ found that the conflicts fell into four groups: the vestigial, the dynamic, the static, and the receding.

$V$ estigial conflicts. At one end of the spectrum are eight conflicts that remain alive, if at all, only in some vestigial form. On some of the issues there is evidence of confusion or uncertainty and perhaps some lingering disagreement; what we do not find is a recent decision that rejects another circuit's precedent. By the same token, there is at most a bare minimum of evidence to suggest that the outcome of any of the cases might have been different in another circuit. Thus, although I am not quite prepared to say that these conflicts have been put to rest, I am confident that they have not given rise to any of the consequences specified by the Federal Courts Study Committee.

Illustrative of this category is Zamboniv Stamler, ${ }^{48}$ a case growing out of the Supreme Court's holding in Connick $v$ Myers ${ }^{49}$ that the First Amendment protects public employees against adverse personnel action only when their speech involves matters of public concern. The petitioner in Zamboni pointed to an apparent conflict on whether the categorization of speech depends on the employee's primary motive in speaking. Justice White, the author of Connick, voted to grant certiorari in the 1988 Term, but he dissented alone. Since then, the lower courts have continued to struggle with the role of motive and intent in public employee speech cases. But the decisions are intensely factual. Although some courts and commentators have identified distinct "approaches," the writers put cases from the same circuit on both sides of the supposed divide. ${ }^{50}$

In these circumstances, the indicia of intolerability are virtually nonexistent. As with most constitutional issues, only one of the Study Committee's factors comes into play: unfairness to litigants

\footnotetext{
${ }^{46}$ In the predictability study, I considered only rejection by another court of appeals. However, for this research I also included rejection by courts of first instance.

${ }^{47} \mathrm{I}$ also looked at earlier decisions, but the classifications are based primarily on developments since January 1, 1994.

${ }^{48} 847$ F2d 73 (3d Cir), cert denied, 488 US 899 (1988) (RN 15).

49461 US 138 (1983).

${ }^{50}$ See, for example, O'Connor $v$ Steeves, 994 F2d 905, 913 (1st Cir 1993); Rosalie Berger Levinson, Silencing Government Employee Whistleblowers in the Name of "Efficiency," 23 Ohio N U L Rev 17, 36-37 n 95 (1996).
} 
in different circuits. Unfairness would exist if, as a result of differences in circuit law, courts were recognizing federal rights in one circuit that were being denied elsewhere. ${ }^{51}$ But that is precisely what the evidence does not show.

Dynamic conflicts. At the other end of the spectrum are 25 conflicts that remain very much alive. These are the "dynamic" conflicts, and the likelihood is high that the choice of rule has affected outcomes in at least some cases. Within this group, I have identified three patterns, rank-ordered as follows (starting with the conflicts manifesting the strongest indicia of intolerability):

- On 10 conflicts, there have been recent decisions that have followed precedents on both sides of the issue, and at least one case on each side has rejected a precedent on the other side. This combination of circumstances provides the strongest evidence that the conflict perpetuates uncertainty and leads to divergent outcomes.

- On 11 conflicts, there have been recent decisions on both sides, and at least one decision from a court not bound by precedent has rejected another circuit's decision or has chosen between competing precedents.

- On four conflicts, although there have not been recent decisions on both sides, at least one court not bound by precedent has rejected another circuit's decision or has chosen between competing precedents.

Even among the conflicts that I have classified as dynamic, there were some that did not affect outcomes, at least on the evidence of reported cases. For example, on the issue of recovery for emotional distress under the Labor Management Reporting and Disclosure Act, ${ }^{52}$ there was only one decision, by a district court in a circuit that had not decided the issue. ${ }^{53}$ The court endorsed the reasoning

\footnotetext{
${ }^{51}$ See Study Committee Report at 125 (cited in note 4) (citing, as illustration of unfairness, conflicts that "allow[] federal benefits in one circuit that are denied elsewhere").

${ }^{52}$ See Guidry v International Union of Operating Engineers, 882 F2d 929 (5th Cir 1989). The issue was presented to the Supreme Court in a later pbase of the long-drawn-out litigation. Guidry $v$ International Union of Operating Engineers, 907 F2d 1491 (5th Cir 1990), cert denied, 498 US 1016 (1990) (RN 640). See discussion in Hellman, By Precedent Unbound at 771 (cited in note 8).
}

${ }^{53}$ Glover v Ossey, 1995 WL 374029 (ND Ill 1995). 
of the Fifth Circuit in the Study Group case, noting that the Fifth Circuit had rejected the approach taken by the Second Circuit. But the judge explicitly indicated that adoption of "the Second Circuit's more restrictive interpretation of actual injury" would not have led to a different outcome. ${ }^{54}$ That, however, is not typical of the conflicts in this group.

Static conflicts. One step removed from the dynamic conflicts are 20 conflicts that can be characterized as "static." The common thread is that precedents on both sides are still good law in their respective circuits, but no court not bound by precedent has chosen between the competing lines of authority. The cases fall into two subgroups.

For mine of the conflicts, there is at least one recent decision in which a court has rejected an out-of-circuit precedent as inconsistent with binding circuit law. However, no court not bound by precedent has rejected another circuit's ruling, nor has any new court chosen between competing precedents. Thus, the conflict has not widened, but the recent reiteration of disagreement gives reason to believe that it will persist. Further, there are at least some cases in which the choice of rule appears to have affected the outcome.

For 11 other conflicts, there have been recent decisions that have followed precedents on both sides, ${ }^{55}$ but no recent decision has rejected any out-of-circuit precedent or chosen between precedents. Generally, these are situations in which the competing circuit positions are well established; thus, it is reasonably clear that the law differs from one circuit to another. What is less clear is that the difference in circuit rules has affected outcomes. Indeed, in some cases there is affirmative evidence that the choice of rule did not control the result.

A good example is the conflict on the standard to be applied to claims by a criminal defendant that jury exposure to extrinsic material requires a new trial. ${ }^{56}$ Under the law of the Tenth Circuit, a new trial is warranted as long as there is the "slightest possibility"

\footnotetext{
${ }^{54}$ Id at ${ }^{*} 10$.

${ }^{55}$ In one instance there has been a decision applying one of the competing precedents but none applying the other.

${ }^{56}$ The issue was presented to the Supreme Court in Sherman v Maryland, 498 US 950 (1990) (RN 627; unpublished decision below).
} 
that the jury's view of the unadmitted evidence affected the verdict. ${ }^{57}$ In contrast, the Seventh Circuit holds that a defendant is entitled to a new trial only if the extraneous material had a "reasonable possibility of prejudicing the jury." ${ }^{58}$ As the Tenth Circuit has recognized, the "slightest possibility" standard is the "less exacting" of the two. ${ }^{59}$ But in August 1996, the Seventh Circuit, applying the "reasonable possibility" standard, affirmed a district court ruling granting a new trial. ${ }^{60}$ Almost simultaneously, the Tenth Circuit applied its more demanding test and denied relief. ${ }^{61}$ Thus, the conflict persists (albeit without recent acknowledgment), ${ }^{62}$ but the verbal standard does not appear to be the dispositive factor in determining case outcomes.

Receding conflicts. Finally, there are what might be called the receding conflicts. A conflict is "receding" when recent decisions have pointed so overwhelmingly in one direction that the precedents on the other side, although not overruled, will carry little weight with lawyers or judges. Under these circumstances, the continuing existence of the conflict is unlikely to make much difference in the outcome of new decisions.

Again, there are two subgroups. In 10 cases, although all recent decisions take one side of the conflict, the authority on the other side still retains some vitality: it has been cited with apparent approval by the court of appeals or applied by a lower court in the minority circuit. But it has not been the basis for a court of appeals decision, so that there has been no opportunity for the minority circuit to reconsider the precedent. Overall, there is substantial evidence that the minority precedent is destined for oblivion, but the obsequies cannot yet be pronounced.

In the remaining 13 cases, courts continue to choose between competing precedents or positions, but recent decisions are all on one side, and the authority on the other side has not been reaffirmed or cited with approval in any recent case. The most one

\footnotetext{
${ }^{57}$ United States v Wood, 958 F2d 963, 966 (10th Cir 1992).

${ }^{58}$ United States $v$ Bruscino, 687 F2d 938, 940 (7th Cir 1982) (en hanc).

${ }^{59}$ Wood, $958 \mathrm{~F} 2 \mathrm{~d}$ at 966.

${ }^{60}$ United States v Berry, 92 F3d 597 (7th Cir 1996).

${ }^{61}$ United States $v$ faramillo, 98 F3d 521 (10th Cir 1996).

${ }^{62}$ The 1992 decision in $W_{0 o d}$ is the only case after 1990 that cites the competing rules on jury exposure to extrinsic evidence.
} 
can say is that the minority precedent may still be good law in its own circuit-and sometimes even that is questionable. For example, the Second Circuit has never overruled its Toscanino ${ }^{63}$ decision, which held that a federal criminal defendant can defeat personal jurisdiction by showing gross illegality in the government's conduct in seizing him overseas. ${ }^{64}$ But no court in the Second Circuit has ever applied Toscanino to dismiss an indictment. ${ }^{65}$

When the precedents on one side have been rejected by every court to consider the issue over a substantial period of time, it is highly doubtful that any of the consequences specified by the Federal Courts Study Committee will ensue. Whether we look at the treatment of litigants in reported cases or at the predictability of future outcomes, the fact that the minority precedent remains on the books is almost an irrelevance. Indeed, if the minority precedent has been sufficiently discredited, the continued existence of the conflict may be regarded as more theoretical than real.

\section{CONCLUSION}

In the 1995 article I presented the results of analyzing the later history of 142 conflicts that were denied review in the 1984 and 1985 Terms. I found fewer than 40 conflicts that (a) were not put to rest by a Supreme Court decision or otherwise, $(b)$ continued to generate litigation, and $(c)$ controlled outcomes in one or more reported cases. How do the results of the new research compare with these findings?

As already noted, complete comparison is not possible because of limited resources for this follow-up study. Nevertheless, the broad patterns are clear enough. Of the 201 conflicts that were denied review in the 1988, 1989, and 1990 Terms, 97 have been put to rest or have otherwise ceased to generate litigation. ${ }^{66}$ Another 36 conflicts plainly have not controlled outcomes in any re-

${ }^{63}$ United States $v$ Toscanino, 500 F2d 267 (2d Cir 1974).

${ }^{64}$ The Phase I Study Group case is Matta-Ballesteros $v$ Henman, 896 F2d 255, 261 (7th Cir), cert denied, 498 US 878 (1990) (RN 604). The issue also appeared in the Phase II Study Group. See Hellman, By Precedent Unbound at 786 n 358 (cited in note 8).

${ }^{65}$ See United States $v$ Yousef, 927 F Supp 673, 676 (SD NY 1996).

${ }^{66}$ This figure includes the 62 conflicts that have been mooted, eliminated, or resolved, along with the 35 conflicts that have been "buried." 
cent reported cases. ${ }^{67}$ That leaves only 68 conflicts that have any potential for affecting outcomes. I am confident that if I applied the criteria used in the study of the 1984 and 1985 Terms, at least 20 of the 68 conflicts would be found not to have produced divergent outcomes in any pair of reported cases for five years or more. ${ }^{68}$

I conclude, therefore, that among the conflicts that have not been put to rest, there are no more than 50 that continue to produce any of the effects that contribute to intolerability. That figure accords closely with the findings reported in the earlier study. And it supports the conclusions previously reached:

1. Simply counting the conflicts that the Supreme Court declines to hear in a particular Term gives a distorted view of the extent to which unresolved intercircuit conflicts pose a problem in the legal system.

2. When one considers both the tolerability of the unresolved conflicts and their persistence, the evidence points strongly to the conclusion that unresolved intercircuit conflicts do not constitute a problem of serious magnitude in the federal judicial system today.

\section{Intercircuit Conflicts and the Practice of Law: Field Research}

As the preceding section demonstrates, the analytical approach can take us a long way toward determining the extent to which unresolved intercircuit conflicts present a problem in the legal system. Nevertheless, reliance on the analytical approach alone is not entirely satisfactory. The premise of the Federal Courts Study Committee is that unresolved conflicts become intolerable when they affect behavior in ways that cause harm. ${ }^{69}$ But the analytical approach can give us only indirect information about how conflicts actually influence behavior. To secure more direct evidence, I undertook a program of field research. The methods I used ultimately included individual and group interviews of attor-

\footnotetext{
${ }^{67}$ This figure includes the 28 conflicts that have evaporated and the eight that I have classified as "vestigial."

${ }^{68}$ I put most of the receding conflicts into this category. Some of the static conflicts can be included as well.

${ }^{69}$ See Hellman, By Precedent Unbound at 708 (cited in note 8).
} 
neys, examination of continuing legal education materials, and an in-depth survey of members of two specialty bars. The work was carried out with the help and support of the Federal Judicial Center $;^{70}$ however, I take sole responsibility for the conclusions.

The field research began where the analytical approach left off. Its purpose was not to secure an independent estimate of the "number and frequency" of unresolved conflicts. ${ }^{71}$ Even if it were possible to obtain quantitative data of that kind through interviews and surveys, the effort would have been difficult and expensive, and it would have made poor use of limited resources. Rather, the purpose was twofold. First, I wanted to pursue questions about the Study Group conflicts that case analysis alone could not answer. Second, I believed that the experiences of practicing lawyers could provide a real-world perspective against which to test conclusions based on the analytical approach. Thus, the field research would address questions such as these: To what extent do conflicts that have the potential for inflicting harm on multicircuit actors actually affect conduct at the primary level? What is the effect of the conflicts on the litigation of federal questions in the lower courts? Where do intercircuit conflicts fit into the totality of factors that influence lawyers' behavior?

The account begins by elaborating on the particular aspects of conflicts that were chosen as the focus for investigation. The remainder of the section describes the methods used, summarizes the results of the research, and explores the implications of the findings.

\section{A. REFINING THE QUESTIONS}

In assessing intolerability through analysis of court decisions and other library materials, I concentrated on looking for characteristics that would correlate with the four nonexclusive factors set forth in the Federal Courts Study Committee report and repeated in Section 302 of the Judicial Improvements Act. For purposes of the field research, however, I did not want to assume that the four factors exhaust the ways in which intercircuit conflicts might affect lawyers' behavior. Rethinking was in order, and that rethinking led

\footnotetext{
${ }^{70}$ For that reason, I sometimes use "we" in describing the method of the study.

"See text accompanying note 15 (quoting the Judicial Improvements Act).
} 
to some modification of the Study Committee framework. One threshold question and one new factor came to the fore, and the considerations listed by the Study Committee took on a somewhat different cast.

Awareness of circuit law. The Study Committee seemed to assume that, as a general matter, lawyers are aware of "the law of the circuit" 72 and take account of circuit differences in planning litigation and advising clients. But the idea of a "law of the circuit" stands on shaky ground, both in theory and in practice. In theory, "[t]he federal courts comprise a single system applying a single body of law." "73 More broadly, in a common law system the assumption is that "all the cases everywhere can stand together." 74 While no one would accept either of these propositions as a description of reality in the federal courts, they do reflect a tradition, and that tradition may be strong enough to affect the way lawyers think about the law, at least in the absence of an acknowledged intercircuit conflict. Moreover, it remains the exception rather than the rule for treatises and practice manuals to focus on individual circuits as espousing particular rules or doctrines. ${ }^{75}$

None of these considerations necessarily negate the premise that lawyers take account of the law of the circuit. Indeed, when a conflict is acknowledged by one or more of the courts or recognized by other authorities, there is every reason to think that the premise is correct. Nevertheless, from an empirical perspective it is necessary to investigate, rather than to take as a given, lawyers' attitudes toward intercircuit differences. This inquiry would embrace questions such as: In the absence of contrary evidence, do lawyers generally treat federal decisional law as a single body of rules, or do they focus on the law of a particular forum, as a lawyer would do

${ }^{72}$ This phrase came into general currency after Judge Friendly used it in the title of a widely cited article. See Henry J. Friendly, The "Law of the Circuit" and All That, $46 \mathrm{St}$ John's L Rev 406 (1972).

${ }^{73}$ H. L. Green Co. v MacMabon, 312 F2d 650, 652 (2d Cir 1962); see also Critical Mass Energy Project v Nuclear Regulatory Comm'n, 975 F2d 871, 881 (DC Cir 1992) (en banc) (Randolph, J, concurring) (although the number of different panels in the 13 circuits may exceed 6,000 , the federal courts, "in theory at least, . . constitute one judicial system.").

${ }^{74}$ Karl Llewellyn, The Bramble Bush 50 (Oceana Publications, 1981; work originally published 1930).

${ }^{75}$ This was the impression I had when I began the field research; it was confirmed during the course of the work. For discussion of one exception, see note 125 and accompanying text. 
today for matters controlled by state law? How much evidence of conflict does it take to arouse suspicion that the choice of circuit may be outcome-determinative? How much weight is given to differences in articulated rules, and how much to patterns in the reported decisions? Does the approach vary depending on the nature of the issue? Are procedural questions treated differently from substantive questions, constitutional issues differently from those governed by statutes? What other variables are taken into account?

Factors not warranting inclusion in field research. For very different reasons, I concluded that two of the factors listed in Section 302 should be omitted from survey instruments for field research. These were nonacquiescence and unfairness.

As shown in the 1995 study, no more than a handful of the conflicts in the Phase I Study Groups even had the potential for "encourag[ing] nonacquiescence by Federal agencies in the holdings of the courts of appeals for different circuits." 76 With instances so few and so scattered, it did not seem worthwhile to formulate questions for the survey instruments to shed further light on their significance. Nor would it have been desirable to impose upon the lawyer respondents the burden of answering inquiries that at best would add only marginally to what we know about the tolerability of unresolved conflicts.

In contrast, the factor of "unfairness to litigants in different circuits" remams very much in the picture. But it is not a factor that lends itself to investigation through surveys and interviews or other field research. "Unfairness" is defined as differential treatment that raises "the sort of equal protection problems which troubled the [Supreme] Court in Erie." 77 The concept thus includes an evaluative component. While, in theory, it might be useful to ascertain the opinions of a representative sample of lawyers as to the unfairness of particular conflicts, the results would be misleading unless the respondents were given full information about the conflict issues and their context. I do not think that it would be possible to provide that information without making the survey instruments hopelessly lengthy and cumbersome.

This does not mean that we must give up on the possibility of

\footnotetext{
${ }^{76}$ Pub L No 101-650, $§ 302,104$ Stat 5089, 5104 (1990); see Hellman, By Precedent Unbound at 742-48 (cited in note 8).

${ }^{77} \mathrm{ld}$ at 757 (quoting Hanna v Plumer, 380 US 460, 468 (1965)).
} 
using field research to add to our understanding of unfairness. If an intercircuit disagreement is important enough to lead lawyers to litigate in one circuit rather than another, we would probably conclude that the conflict does result in differential treatment of a kind that would be deemed unfair. Thus the inquiry into unfairness could be pursued by asking lawyers about forum shopping. That aspect of the research is discussed below.

Harm to multicircuit actors. Intercourt conflicts arouse greatest concern when they impose inconsistent directives to govern the same primary conduct. ${ }^{78}$ Almost as troublesome, in a system that accords nationwide precedential effect only to decisions of the United States Supreme Court, ${ }^{79}$ are conflicts that force multicircuit entities to choose between disuniformity in their operations and obedience to the unfavorable rule of a single circuit. These are the consequences that the Federal Courts Study Committee referred to when it spoke of conflicts that "impose economic costs or other harm to multi-circuit actors." 80

Of the conflicts identified in Phase I, about one-quarter-just over 50 -had some potential for inflicting injury of this kind. For the most part, though, that classification meant only that, on the basis of subject matter and the nature of the issues, the possibility of harm to multicircuit actors could not be ruled out. Whether harm in fact occurred would depend on factors that would not necessarily be reflected in library materials. One purpose of field research is to ascertain the extent to which the scenarios hypothesized by the Federal Courts Study Committee have actually been played out in law offices and boardrooms.

That is not an easy task. The most formidable challenge is to isolate the harms caused by intercircuit conflict from those attributable to uncertainty stemming from other aspects of the legal system. For example, the Guide to Antitrust Compliance prepared by a food company observes that "there is no consensus among courts as to what constitutes unlawful predatory pricing."

\footnotetext{
${ }^{78}$ See Arthur D. Hellman, Breaking the Banc: The Common-Law Process in the Large Appellate Court, 23 Ariz St L J 915, 922-23 (1991).

${ }^{79}$ See Hellman, By Precedent Unbound at 743 (cited in note 8).

${ }^{80}$ Study Committee Report at 125 (cited in note 4).

${ }^{81}$ American Bar Ass'n Section of Antitrust Law, Compliance Manuals for the New Antitrust Era 201 (1990). Another company's guide says only, "This is a complex area of the law." Id at 336.
} 
like a reference to intercircuit conflict. But the writer might also be using "courts" in a less technical sense that encompasses different panels of the same court. After all, perceptions of conflict within circuits on that particular issue are not unknown. ${ }^{82}$

This ambiguity probably will not arise when the conflict issue is binary and discrete. That is not the norm, however, and in other situations the consequences of the unresolved intercircuit conflict will be more difficult to disentangle. I have in mind a recurring pattern in the cases in the Random Group: the conflict is acknowledged or recognized, but the issue is not binary, and within at least some of the circuits there are multiple precedents that point in different directions. In this setting, multicircuit actors might well experience difficulty in ordering their affairs in a way that would yield predictable outcomes if disputes were to go to court. But these circumstances also make it unlikely that outcomes will be determined by the choice of one circuit's law over another's. Thus, from the perspective of the Section 302 factors, it cannot be said that the conflict has imposed economic costs. Careful formulation of the questions is required in order to secure responses that shed light on the single aspect of precedent that is the subject of this research. $^{83}$

Forum shopping. In the course of analyzing the conflicts in the Phase I Study Group, I concluded that forum shopping among circuits becomes an evil only when it causes harm to multicircuit actors or results in unfairness to litigants in different circuits. ${ }^{84}$ Thus, the possibility of "encourag[ing] forum shopping" should be given no independent weight in evaluating the consequences of an unresolved conflict. By the same token, however, when conflicts do affect the selection of a forum, we have strong evidence that

\footnotetext{
${ }^{82}$ See, for example, William Inglis \& Sons Baking Co. v ITT Continental Baking Co., 668 F2d 1014, 1060 (9th Cir 1981) (Wallace, J, dissenting from denial of rehearing en banc). The writer might also have been referring to disharmonies between federal and state courts. See generally William J. Haynes, Jr., Will the Answers Be Different Under State Antitrust Laws? in 34th Annual Advanced Antitrust Seminar: Distribution and Marketing at 519 (Practicing Law Institute, 1995).

${ }^{83}$ Implicit in this discussion is the view that conflict between circuits is only one of the ways in which the operation of the system of precedent may fail to satisfy the desires of lawyers and citizens for predictability and uniformity in the law. Implicit, too, is the suggestion that the effect of intercircuit conflict cannot be fully assessed without consideration of other sources of uncertainty.
}

${ }^{84}$ See Hellman, By Precedent Unbound at 754-56 (cited in note 8). 
the choice of rules is important to a degree that will implicate the other two factors. In the context of field research, this means that forum shopping can serve to some extent as a proxy for unfairness and the possibility of harm to multicircuit actors.

Forum shopping also appears to be a phenomenon that is relatively straightforward to investigate. Choosing a forum after the decision has been made to pursue litigation will generally be a discrete, one-time event that lawyers will be able to describe with relative ease. Thus, focusing on specific conflicts identified in Phase I, we planned to ask such questions as: Had the lawyer encountered the conflict in his or her practice? Under what circumstances, if any, would the different rules lead the lawyer to file suit in one circuit rather than another? In disputes growing out of continuing relationships, would the lawyer initiate a "preemptive strike" to assure litigation in a circuit with a favorable rule? How much weight would the lawyer give to the presence of an intercircuit conflict in comparison with other factors that bear upon the choice of forum?

Effect on litigation in other circuits. Choice of forum is not the only aspect of litigation that may be affected by the existence of an intercircuit conflict. Review of the literature suggested one additional consequence not mentioned in the statute or the Federal Courts Study Committee report (though it has been discussed by the chairman of the Study Committee) ${ }^{85}$ that appeared to warrant investigation through field research. The area of inquiry involves the effect on litigation and motions practice in circuits where the court of appeals has not ruled on the issue. For example: other things being equal, would a lawyer be more apt to litigate rather than settle when there are court of appeals decisions on both sides than when the only circuit precedent was against him? Once litigation is in progress, would the conflict influence the lawyer to pursue a point (or pursue it with more vigor)? How does the conflict situation compare with the situation where no circuit has ruled on the issue? In short, does the existence of a conflict encourage relitigation of issues that might otherwise be regarded as not worth litigating?

${ }^{85}$ Statement of Judge Joseph F. Weis, Jr., Before the Subcommittee on Courts and Adininistrative Practice of the Senate Judiciary Committee at 14-15 (Oct 3, 1991). 


\section{B. METHODS FOR ASCERTAINING IMPACT}

To ascertain the actual impact of unresolved conflicts on counseling and litigation, I expected to use conventional techniques of field research such as mail surveys, in-person interviews, telephone interviews, and group discussions or focus sessions. The survey instruments would describe a group of conflicts selected from among those identified as having some potential for encouraging forum shopping or inflicting harm on multicircuit actors. ${ }^{86}$ With respect to each conflict, the lawyer respondents would be asked such questions as: Were they aware of the conflict before we called it to their attention? Did it offer any opportunity for forum shopping? If so, would the lawyers take advantage of the opportunity? What economic costs, if any, would the inconsistent rules impose on clients operating in more than one circuit?

The first step was to define the population from which the interviewees and survey respondents would be selected. Plainly, it would not have served the purpose to draw from a random group of lawyers, or even from a random group of lawyers practicing in the federal courts. The consequences that I was investigating would generally be experienced only by two classes of attorneys: those who represent national corporations, pension funds, and other entities whose activities cross state lines; and those who regularly represent individuals with claims against such entities. In addition, I wanted to maximize the likelihood that the respondents would have encountered more than one or two of the conflict issues.

With these considerations in mind, I decided to limit the field research to areas of law that gave rise to half a dozen or more conflicts in the Phase I Study Group. Four areas of federal practice fit that description: antitrust, ERISA, labor and employment, and maritime law. ${ }^{87}$ For each of those areas I compiled an annotated

${ }^{86}$ This approach meant that I excluded conflicts whose existence might encourage relitigation, but which were unlikely to influence the choice of forum or affect the primary conduct of multicircuit actors. I did not think this category was large, and in any event there were other reasons for limiting the scope of the research.

${ }^{87}$ Maritime law harely qualified, but I included it anyway because the preliminary report of the Federal Courts Study Committee made explicit mention of conflicts on maritime issues. Federal Courts Study Committee, Tentative Recommendations for Public Comment I 19 (Dec 22, 1989). The reference was not included in the Study Committee's final report. 
list of the conflict issues for inclusion in the survey instruments. The lists included not only the Phase I conflicts, but also the conflicts in that particular area from the Phase II Study Group.

The research proceeded in four stages, each shaped by the ones that preceded it. I began by conducting a series of in-person interviews with experienced lawyers who specialized in one of the four fields I had selected. ${ }^{88}$ Some of the interviews were one-on-one; others included small groups of lawyers practicing in a particular city. These discussions advanced the inquiry in several ways. They yielded valuable insights into the role of precedent in the lawyering process. They gave me a general sense of how lawyers viewed conflicts. And they provided information that helped me to frame questions that would be addressed to a broader population of practitioners.

Partly on the basis of the interviews, I made one change in the scope of the research: one of the four areas-labor and employment law-was omitted from further investigation. Although the number of conflicts in that area was substantial, the conflicts themselves were generally among the weakest in the Study Groups. Not surprisingly, even experienced labor and employment lawyers had paid little attention to them. In that situation, I saw no more than a small likelihood of securing the kind of specific information I wanted about the effects of the conflicts on the practice of law.

I was more optimistic about the prospect of obtaining useful responses from specialists in maritime law, antitrust, and ERISA. However, resources would not permit extensive in-person interviewing. I therefore decided to try a different approach: examining published materials written by lawyers for the guidance of other lawyers. Included in this category are such works as course outlines for continuing legal education (CLE) programs and practiceoriented treatises. The value of these materials lies in the combination of authorship and purpose. The authors are individuals whose background and stature would have made them likely candidates for interviews or surveys if I were to continue with the method of posing questions to experienced lawyers in the three areas of the law. The purpose of the materials is to assist practicing attorneys

\footnotetext{
${ }^{88}$ I began with specialists for two reasons. First, they were more likely to have encountered the conflicts in their own practice. Second, they could speculate knowledgeably about how other lawyers would deal with the conflicts they had not personally experienced.
} 
in counseling and litigation. ${ }^{89}$ Thus, to the extent that the existence of an intercircuit conflict would affect those activities, whether positively (as opportunities) or negatively (as pitfalls), we would expect the experienced authors to call attention to them. ${ }^{90}$ If, in this context, nothing is said, or if there is no suggestion that lawyers should modify their behavior to take account of the conflict, this is evidence that the conflict will not give rise to any of the consequences that concerned the Federal Courts Study Committee.

Two of the three fields that I was investigating-antitrust and ERISA-have generated numerous CLE outlines, treatises, and other practice-oriented materials. As a first step, student assistants used conventional tools of legal research to search those materials for discussions of the conflict issues identified in Phase I and II. I then analyzed the materials to see what each author had to say about each conflict. Did the writer mention the conflict at all? If so, did the text elaborate, even minimally, on the consequences of the conflict for lawyers or their clients? ${ }^{91}$ Was there any suggestion, direct or indirect, that the difference in circuit law would warrant litigating in one forum rather than another? ${ }^{92}$ Was there any indication, direct or indirect, that the advice to be given a client, or the course of action to be taken, would vary depending on which circuit's law was controlling??3

\footnotetext{
${ }^{89}$ See, for example, Carla A. Hills, ed, Antitrust Adviser v (3d ed 1985) ("The Antitrust Adviser was written to assist the practitioner who represents business clients to circumvent antitrust problems ... and to respond appropriately to antitrust controversy when it does arise.").

${ }^{90}$ For illustrations, see authorities cited in notes 91-93.

${ }^{91}$ For example, a lawyer might warn that structuring a transaction in accordance with the law of the circuit poses risks because other courts of appeals have ruled differently. See, for example, Gregory C. Yadley and Kent Schenkel, Sharebolder Guaranties of Corporate Debt: Considerations in Drafting and Structuring, Fla Bar J (Oct 1991) at 39, 42 (suggesting different approach to borrowings because of the "uncertainty [that] reigns in this area"). Or a writer might simply note that the conflict creates problems for a particular class of individuals. See, for example, Ralph C. Losey, Bruch Creates Split in Circuits on Standard of Appellate Review, Natl L J (Nov 4, 1991) at 20 ("The conflicting interpretations of 'de novo' [in reviewing benefit claim denials] cause headaches for insurance companies and ERISA plan administrators."). The author does not elaborate on the nature of these "headaches."

${ }^{92}$ See, for example, Jed S. Rakoff and Howard W. Goldstein, RICO: Civil and Criminal Law and Strategy $\$ 7.03[2][\mathrm{a}]$ (1992) ("A RICO plaintiff should consider the receptivity of the district court and circuit to private civil RICO."). This suggestion, of course, directs the lawyer's attention to the totality of circuit law, not its position on one particular issue.

${ }^{93}$ See, for example, R. Quincy White and Sandy L. Koropp, Circuits Split on Color Trademarks, Natl L J (May 5, 1993) at S17 (until Supreme Court resolves the issue of whether color can serve as a trademark, "those wishing to protect color as a tradenıark in the 7th
} 
The research yielded voluminous material, with half a dozen or more references for some of the issues that we investigated. However, we found very little evidence to indicate that the Study Group conflicts influenced lawyers' decisions or shaped advice to clients.

For some of the conflicts we could find no mention at all in the materials we examined. Some conflicts were discussed only in passing, suggesting that the point of difference did not loom large even in the eyes of specialists. By far the most common form of discussion was what might be called the academic reference: the author would cite the Study Group case and note the conflict, but would not elaborate in any way on the significance of the conflict for the practice of law. These references did not describe how an experienced practitioner might act in the face of conflicting authority, nor did they allude, even in general terms, to any difficulties that the existence of the conflict might create.

We did find some references that went beyond citation or description. For example, a compliance guide to price discrimination, prepared for a CLE program held early in 1994, took note of the conflict on what constitutes below-cost pricing, then added, "Thus, counsel should check the caselaw in its circuit to find out which measure [of cost] governs." 94 A discussion of asset reversions under ERISA explicitly noted the possibility of "successful forum shopping." 95 But these were exceptions.

What conclusions could we draw from this body of evidence? One possible explanation is that conflicts that have the potential for harming multicircuit actors or encouraging forum shopping among circuits generally do not do so. That conclusion would have been consistent with the overall thrust of the interviews up to that

Circuit should attempt to protect the color only in connection with a symbol or design"). The question whether color can be protected as a trademark gave rise to one of the conflicts in the Phase I Study Group. See NutraSzeet Co. v Stadt Corp., 917 F2d 1024 (7tb Cir 1990), cert denied, 499 US 983 (1991) (RN 664). The Supreme Court resolved the conflict in the 1994 Term. See Qualitex Co. v Jacobson Prods. Co., 514 US 159 (1995).

${ }^{94}$ Barbara A. Reeves, Price Discrimination: A Compliance Guide, in 33rd Annual Advanced Antitrust Seminar: Distribution, Marketing, and Joint Ventures at 471, 479 (Practicing Law Institute, 1994). The author was actually referring to pricing claims under the RobinsonPatman Act, rather than Section 2 of the Sherman Act, which was the subject of the Study Group conflict. However, the two issues often overlap.

${ }^{95}$ Michael S. Gordon, Asset Reversion Litigation-the Plaintiff's Perspective, in Employee Benefits Litigation, C507 ALI-ABA 593, 596 (1990) (available on Westlaw). The comment is quoted in full in text accompanying note 118. 
point, and indeed the lawyers I interviewed had pointed to a number of reasons why conflicts might play a smaller role in practice than an academic perspective might suggest. ${ }^{96}$

Notwithstanding the strong pattern that was emerging, I was reluctant to treat negative evidence as conclusive. A high proportion of the material consisted of outlines for CLE programs, and I could not exclude the possibility that more extended discussion of the conflicts took place in the oral presentations. To provide a check on inferences drawn from the absence of affirmative evidence, I embarked on another series of interviews. This time I talked to attorneys who had served as faculty for CLE programs or who had written practice-oriented treatises or guidebooks in the field of antitrust. ${ }^{97}$ The interviews were conducted by telephone.

Overall, the interviews tended to confirm the impressions given by the written materials: intercircuit conflicts simply do not loom large in the decisions and actions of the practicing bar. I recognized, however, that the number of lawyers interviewed was small, and that their responses might not represent an adequate range of experiences. For that reason, I decided to conduct a survey that would reach a somewhat broader sample of the bar. The survey was designed and carried out with the assistance of the Federal Judicial Center.

The survey was limited to two fields of practice: maritime law and antitrust. Maritime law was chosen because it is the only federal "specialty" in which the organized bar has expressed concern about unresolved intercircuit conflicts. ${ }^{98}$ Antitrust was selected primarily because our interviews indicated that the Study Group cases included a high proportion of conflicts that were familiar to the bar. In addition, I felt that there would be value in comparing responses from maritime lawyers with responses from members of

\footnotetext{
${ }^{96}$ For discussion, see Section D.

${ }^{97}$ I did not limit the survey population to lawyers who had written about the specific conflicts I was investigating. Much of the written material was coauthored, and some dated back several years. Thus, identifying the authors of particular sections of an outline or article would have taken time and effort that I did not think would be worthwhile.

${ }^{98}$ In I989, the Maritime Law Association of the United States submitted a report to the Federal Courts Study Committee that discussed nine intercircuit conflicts on maritime law issues. A copy of the report is on file with the author. See also Michael F. Sturley, Observations on the Supreme Court's Certiorari furisdiction in Intercircuit Conflict Cases, 67 Tex L Rev 1251 (1989) (arguing that the Supreme Court has erred in failing to resolve conflicts involving COGSA).
} 
a specialty bar that has not viewed conflicts as a significant problem. ${ }^{99}$

For the maritime survey, we obtained a mailing list from the Maritime Law Association of the United States. The list was limited to "proctor members"-members with at least four years' experience who have demonstrated "proficiency" in admiralty. ${ }^{100}$ For the antitrust survey, we used a list drawn from the leadership group of the Antitrust Section of the American Bar Association. We mailed a total of 505 surveys to maritime lawyers; the number returned was 162. The rate of return on the antitrust surveys was lower-only 82 out of 447 .

Although the survey instrument included some general questions, our primary interest was in ascertaining the respondents' experience with the specific conflicts identified in the earlier phases of the study. Drawing on information gained in interviews, we selected eleven conflicts in maritime law and eleven in antitrust. For each conflict, a booklet included with the survey instrument provided a statement of the issue and a citation to the cases on both sides. We asked the lawyers to select the three conflicts with which they were most familiar and then to answer two sets of detailed questions about those conflicts. One set of questions focused on the particular conflict's effect on the practice of law generally; another set asked about the respondent's most recent encounter with the conflict in litigation or counseling. The survey instrument also gave the participants a chance to comment on the issues or expand on their answers. ${ }^{101}$

The survey responses substantially augmented the data obtained through interviews. The analysis that follows is based on both bodies of material.

\section{FINDINGS}

When the field research for this project began, there were 68 conflicts that I planned to investigate: 14 in antitrust, 32 in labor

\footnotetext{
${ }^{99}$ ERISA too would have served this purpose, but investigating the ERISA conflicts would have required surveying the several specialty bars that regularly handle ERISA matters. Resource limitations precluded such an undertaking.

${ }^{100}$ See Robert M. Jarvis, Admiralty: 1991 Survey of Florida Lazw, 16 Nova L Rev 127, 134 n 50 (1992) (describing qualifications for proctor membership).

${ }^{101}$ Copies of the survey materials are on file with the author and with the Federal Judicial Center.
} 
and employment law, 10 on ERISA issues, and 12 in maritime law. ${ }^{102}$ As the research proceeded, however, the pool of conflicts shrank considerably.

The first dropouts were the conflicts on labor and employment law. As noted in the preceding section, interviews with lawyers led me to conclude that the conflicts in that field had such a low level of visibility that it would not have been fruitful to seek detailed information about practitioners' experience with them.

No other area was dropped entirely from the research. However, some individual conflicts were omitted because they appeared, on the basis of the initial interviews and the practice materials, to be too narrow or unimportant to warrant further investigation. Thus, in the final stages of the field research I was concentrating on 30 conflicts: 11 each in maritime law and antitrust, and 8 on ERISA issues. The surveys, interviews, and practice materials shed light on six aspects of those conflicts: their incidence, their effects on outcomes, the extent to which they led to forum shopping, their other effects on litigation, their effects on primary activity, and the legal context of the conflicts. The most useful information came from the surveys of the maritime and antitrust bars; thus, in this section, I rely primarily on the survey responses as the basis for analysis.

Incidence of the conflicts. To put the more specific responses into context, we must know how frequently the conflict issues arose in practice. Reported decisions give us valuable clues, but they do not tell the whole story. Some issues may generate judicial opinions on a scale disproportionate to their incidence in life. Others may be important in primary activity even though they do not often appear in judicial opinions.

The maritime and antitrust surveys included several questions that shed light on the incidence of the 22 conflicts in those areas. First, we asked the participants whether they had personally encountered the conflicts either in counseling or in litigation. A single encounter would have sufficed for an affirmative response, but for seven of the maritime conflicts and three in antitrust, affirmative answers came from fewer than half of the participants. Three maritime conflicts and one in antitrust had response rates under 30 percent.

\footnotetext{
${ }^{102}$ As explained in the discussion of methods, these numbers include some conflicts from the Phase II Study Group.
} 
Next, we asked the respondents to select the three conflicts with which they were most familiar, or with which they had had the most experience. Three maritime conflicts and three in antitrust were selected by fewer than 15 lawyers. Not surprisingly, the six conflicts selected least often were, with one exception, the same ones that drew the smallest number of positive responses to the earlier question. ${ }^{103}$

Taking both sets of replies into consideration, we may reasonably conclude that five of the survey conflicts did not arise very often. The antitrust conflicts in this category are those involving price squeezes in regulated industries ${ }^{104}$ and jurisdiction over foreign entities. ${ }^{105}$ In maritime law, the conflicts involved preemption by the Longshore and Harbor Workers' Compensation Act (LHWCA) $)^{106}$ and the penalty wage statute. ${ }^{107}$ The six conflicts that were selected by fewer than 15 lawyers for detailed responses will not be further discussed here.

The remaining conflicts-a total of 16 - will be referred to as the "core group" of antitrust and maritime conflicts. ${ }^{108}$ This designation reflects a relative ranking. It does not necessarily mean that the conflicts in the core group arose with great frequency, and indeed there is evidence that most of them did not. One of the questions we posed to the lawyers about the conflicts they had chosen for detailed consideration was, How often had the conflict issue been relevant to the resolution of a dispute in the lawyer's area of practice? The respondents reported their experiences on a

${ }^{103}$ The exception occurred in antitrust. Although morc than half of the respondents said they had encountered the conflict on the role of intent in predatory pricing, only eight selected it for detailed discussion.

104 The conflict case was Town of Concord $v$ Boston Edison Co., 915 F2d 17 (1st Cir 1990), cert denied, 499 US 931 (1991) (RN 659). See Hellman, By Precedent Unbound at 717 (cited in note 8).

105 The conflict case was Timberlane Lumber Co. $v$ Bank of America, 749 F2d 1378 (9th Cir 1984), cert denied, 472 US 1032 (1985) (Phase II case; RN 844). See Hellman, By Precedent Unbound at 788 (cited in note 8).

${ }^{106}$ The conflict case was Crater $v$ Mesa Offshore Co., 539 So2d 88 (La), ccrt denied, 493 US 905 (1989) (RN 176). Sec Lewis v Modular Quarters, 487 US 1226 (1987) (White, J, joined by Blackmun, J, dissenting from denial of certiorari) (noting conflict).

107 There were two conflicts involving the pcnalty wage statute. Both are noted in Hibernia Nat'l Bank v Cbung, 475 US 1147 (1986) (White, J, dissenting from denial of certiorari) (RN 935 and RN 963; Phasc II case).

${ }^{108}$ Four of the eight antitrust conflicts were selected by fewer than 20 lawyers. Further, some respondents did not answer all questions about the conflicts they had chosen. The antitrust results are thus lcss reliable than those based on the maritime survey. 
scale of 1 ("rarely or never") to 5 ("very often"). For convenience, I shall refer to 1 and 2 as the "low end" of the scale; 4 and 5 will be referred to as the "high end." 109

For all but two of the antitrust conflicts, responses at the low end outnumbered responses at the high end. For the other two antitrust conflicts, the numbers at both ends were equal. In the maritime survey, responses at the low end outnumbered responses at the high end for three of the eight conflicts in the core group. These patterns suggest that all of the antitrust conflicts and three of the eight in maritime law may have come into play less often than the initial data imply.

The field research did not furnish a sufficient basis for assessing the incidence of the eight ERISA conflicts. As already noted, resource limitations precluded use of the survey technique in that area of law. Case reports, commentaries, and interviews provided some information about the frequency with which the conflicts arose, but not enough to warrant confident estimates. ${ }^{110}$

Effect on outcomes. As emphasized throughout this article, a conflict is unlikely to give rise to any of the consequences that concerned the Federal Courts Study Committee unless it affects (or can be expected to affect) the outcome of a litigation. We therefore asked the survey respondents whether, in cases where the conflict issues were relevant, application of one circuit's law rather than another's determined the result.

The perception that conflicts were outcome-determinative was strongest within the maritime bar. Of the eight conflicts in the core group, five produced more responses at the high end of the frequency scale than at the low end. Yet even here the evidence was by no means one-sided. For each conflict, at least 30 percent of the responses were at the low end of the scale.

On antitrust issues, the survey responses indicate that the conflicts generally were not outcome-determinative. Seven of the eight core conflicts drew more responses at the low end of the scale than at the high end. For the remaining conflict (involving dealer termination as a per se violation of Section 1 of the Sherman Act), the numbers at both ends were the same. ${ }^{11}$

\footnotetext{
${ }^{109}$ This convention will be used throughout this article.

${ }^{110}$ Two of the ERISA conflicts were resolved shortly after the denial of review in the Study Group cases. See Section E.

${ }^{111}$ For discussion of this issue, see text accompanying notes 153-56.
} 
Forum shopping. When an intercircuit conflict remains unresolved, a federal judge has written, "attorneys [will] take their cases to the forum most favorable." 112 That is a plausible supposition. But is it an accurate description of lawyers' behavior? To find out, we asked the survey respondents how often the specific conflicts led lawyers to file suit in one circuit rather than another.

In the field of antitrust, the results indicate that conflict-based forum shopping is not a common litigation tactic. Of the eight conflicts in the core group, only one produced more responses at the high end of the frequency scale than at the low end. This was the conflict over whether a plaintiff can prevail on a tying claim without showing power over price in the relevant market by showing the uniqueness of the tying product. ${ }^{113}$ One other conflict, involving dealer termination as a per se violation, generated a substantial number of high-end responses, though not as many as those at the low end.

In the field of maritime law, the survey data provide strong evidence that conflicts generally do not lead lawyers to file suit in one circuit rather than another. For every one of the eight core conflicts, responses at the low end of the frequency scale substantially outnumbered responses at the high end. Indeed, high-end responses rose above the 20 percent mark for only three of the conflicts.

Of particular interest is the pattern of responses on conflicts involving the Carriage of Goods by Sea Act (COGSA). Professor Michael F. Sturley, a prominent maritime law scholar, has stated that "[c]onflicts under COGSA are precisely the type most likely to be intolerable, because litigants can easily exploit them through forum shopping." 114 The conflicts in the questionnaire included three COGSA issues, two of which were discussed by Professor Sturley. ${ }^{115}$ However, the evidence of forum shopping is meager in-

${ }^{112}$ Roger J. Miner, Federal Court Reform Should Start at the Top, 77 Judicature 104, 106 (1993).

${ }^{113}$ The Study Group case was Will v Comprehensive Accounting Corp., 776 F2d 665 (7th Cir 1985), cert denied, 475 US 1129 (1986) (Phase II case; RN 931).

${ }^{114}$ Sturley, 67 Tex L Rev at 1268 (cited in note 98). Professor Sturley contrasts COGSA with the LHWCA, saying, "LHWCA itself prevents most forum shopping." Id at 1260.

${ }^{115}$ Professor Sturley discussed the conflict on the effect of a deviation from the carriage agreement (RN 951) and the conflict on the burden of proof on the "fire" defense (RN 713). Id at 1266-68.The third COGSA issue involved the "inherent vice" defense (RN 715). 
deed. For two of the issues, responses at the low end outnumbered responses at the high end by a ratio of 6 to 1 . For the third issue, the ratio was almost 3 to 1 .

Why do lawyers not take advantage of the venue options that Professor Sturley describes? One probable explanation is that the conflicts are not perceived as outcome-determinative. But it is also likely that when lawyers decide where to file suit, differences in circuit law pale in importance when weighed against other considerations. ${ }^{116}$ Finally, venue options in commercial litigation may be limited by forum selection clauses in the bill of lading. ${ }^{117}$

One of the most explicit discussions of forum shopping in the practice materials dealt with a conflict involving ERISA. The subject was asset reversions. The author stated:

Obviously, jurisdictions which are clearly inhospitable to plaintiffs' theories on asset reversions should be avoided where possible. An asset reversion in a nationwide or multistate pension plan may lend itself to successful forum shopping. Close attention should be paid to relevant circuit court opinions that will govern the federal district courts where the asset reversion action may lie. ${ }^{18}$

We have no way of knowing whether, and to what extent, lawyers paid heed to this suggestion. However, the responses to the antitrust and maritime surveys strongly point to the conclusion that, for the most part, intercircuit conflicts do not lead to forum shopping.

This conclusion is also supported by the interviews. The predominant attitude among lawyers was nicely captured by an experienced litigator in the field of antitrust. The lawyer characterized the survey conflicts as "good examples, but narrow," and said that they would not be dispositive in choosing a forum. The lawyer added, "I can't remember an instance where we're down to our last conference call and someone has said, "If we file there, we'll lose!" "

\footnotetext{
${ }^{116}$ See Section IIID.

${ }^{117}$ Although some courts have refused to enforce forum selection clauses in contracts subject to COGSA, others have found such clauses to be valid, especially when the designated forum was one within the United States. See generally C. Andrew Waters, The Enforceability of Forum Selection Clauses in Maritime Bills of Lading: An Update, 15 Tulane Maritime L J 29 (1990). The Supreme Court recently held that COGSA does not invalidate foreign forum selection clauses. Vimar Seguros Y Reaseguros, S.A. v M/V Sky Reefer, 515 US 528 (1995). Presumably the holding applies a fortiori to clauses designating a domestic forum.

${ }^{118}$ Gordon at 596 (cited in note 95 ).
} 
Otber effects on litigation. Even if conflicts do not generally lead to forum shopping, they may add to the complexity or cost of litigation in the forum that is chosen. The survey responses indicate that, to some extent, this does occur.

We asked the survey participants how often additional cost or complexity had resulted from the conflicts they had selected for detailed discussion. Four of the maritime conflicts and five of those in antitrust engendered more responses at the high end than at the low end. Thus, some conflicts that seldom influenced the choice of forum did have some effect on the shape or course of the lawsuits that were filed.

This result is contrary to what I would have expected. Nevertheless, its significance should not be overstated. High-end responses remained below the 50 percent mark for all of the maritime conflicts and for all but two of those in antitrust. In other words, conflicts may result in added cost or complexity more often than they lead to forum shopping, but that does not necessarily mean that the former occurs often in absolute terms. To find out whether it did, we must delve further into the survey responses.

In addition to the frequency question, I asked the lawyers to think back to the last time they had encountered each of the selected conflicts in a litigation situation and to state whether the existence of the conflict had affected the litigation (other than by influencing the choice of forum). Among the maritime conflicts, only one generated more "yes" than "no" answers. This was the conflict on recovery for economic loss in admiralty. ${ }^{119}$ Among the antitrust conflicts, "no" answers outnumbered "yes" responses for all eight core conflicts. Many of the antitrust participants did not answer this question at all.

These patterns cast doubt on the hypothesis that unresolved conflicts frequently result in added cost or complexity in litigation. However, we need not rely solely on a tally of one-word answers. When participants said "yes" to the question about effect on litigation in the most recent encounter, we asked them to explain their

${ }^{119}$ The conflict was presentcd to the Court in the 1984 Term and again in the 1989 Term. The later case was Texas Eastern Transmission Corp. $v$ McMoRan Offshore Exploration Co., 877 F2d 1214 (5th Cir), cert denied as Marathon Oil Co. v McMoRan Offshore Exploration Co., 493 US 937 (1989) (RN 286). For discussion of the issue see Hellman, By Precedent Unbound at 791 (cited in note 8). 
response. We received a total of 165 such comments from the maritime lawyers and 36 from participants in the antitrust survey. ${ }^{120}$

About 20 percent of the comments shed no light on whether the conflict had added to the cost or complexity of the particular litigation. The respondent simply recited the procedural history, described the result, or identified the aspect of the suit that was affected. Included in this category are responses that referred to settlement or settlement discussions but did not explain further.

Another, somewhat larger, group of explanations focused on consequences distinct from added cost or complexity. For example, some lawyers representing maritime defendants reported that plaintiffs had filed suit in state court. Other respondents simply noted the effect of applying the particular rule in force in the circuit or argued that the court had interpreted the law erroneously. Some of the maritime respondents said that the existence of the conflict had facilitated or encouraged settlement.

The remaining comments indicated, with varying degrees of explicitness or clarity, that the conflict had indeed added to the cost or complexity of the particular litigation. Some of the respondents spoke in general terms of increased expense or difficulty. Others referred to more specific consequences. Here are some representative examples from the maritime survey:

- "Opposing counsel used conflict to urge change of law in my circuit." (Conflict on punitive damages for injuries incurred by seamen. $)^{121}$

- "Substantial amount of research time; briefing [and] preparation of jury charges." (Conflict on definition of "seaman" under Jones Act.)

- "Increased risk of appeal and made settlement more difficult." (Conflict on punitive damages.)

- "It affected the amount and structure of evidence (and its cost) in the effort to vitiate the conflict." (Conflict on shipowner's liability for injuries arising out of defective stowage.)

\footnotetext{
${ }^{120}$ The comments are brief and generally conversational in style. They are useful for discerning broad patterns, but they should not be viewed as a source of hard quantitative data.

${ }^{121}$ The same lawyer said of another conflict, "The conflict allowed me to argue for a change in the law." (Conflict on effect of deviation under COGSA.)
} 
Here are some responses from the antitrust participants:

- "Required to brief both possibilities [to] demonstrate why requested result should not be changed." (Conflict on definition of "sham" under Noerr-Pennington doctrine.)

- "Ambiguity on law 'encourages' clients on both sides of issue. Tougher to settle or otherwise quickly resolve." (Conflict on business justification defense under section 2.)

- "Uncertain state of law made settlement discussions difficult." (Conflict on essential facilities doctrine.)

Other comments, however, were considerably more ambiguous. For example, a substantial number of respondents spoke of uncertainty or unpredictability, but did not say that this uncertainty had resulted in increased cost or other tangible consequences. Other participants referred to "bad jury instructions" or to results adverse to the client, but did not point to added cost or complexity en route.

On balance, the explanatory comments indicate that conflicts do sometimes add to the cost or complexity of litigation. However, the survey data as a whole suggest that the phenomenon is not a common one. The survey responses encompass more than 500 encounters with the 16 core conflicts. But the total number of affirmative answers to the question focusing on the respondent's most recent encounter was less than 200. And little more than half of those alluded, even ambiguously, to added cost or complexity.

Effect on primary activity. Thus far the discussion has focused on the effect of conflicts on litigation. We also attempted to determine how the conflicts affected lawyers in counseling and the structuring of transactions. We did this in two ways. For each of the issues selected for detailed response by the survey participants, we asked, in general terms, how often the existence of the conflict added to the difficulty of advising a client in a counseling situation. In addition, we asked the lawyers to focus on their most recent encounter with that conflict. The questions then were: "Did the existence of the conflict affect the advice that you gave to the client? If Yes, please explain."

The picture that emerged was a complex one. Of particular im- 
portance, when we looked at the explanatory comments, we discovered that the antitrust and maritime lawyers approached the "counseling" questions from very different perspectives. The antitrust lawyers responded primarily by describing advice they had given in the context of primary conduct and the structuring of transactions. ${ }^{122}$ The maritime lawyers generally talked about particular incidents that had led, or might have led, to the filing of a lawsuit. ${ }^{123}$ The two groups will therefore be discussed separately.

In antitrust, the answers to the more general question strongly indicated that the conflicts did make counseling more difficult. Responses at the high end of the frequency scale outnumbered responses at the low end for all eight of the core conflicts. For all but two of the conflicts, the ratio was 2 to 1 or higher.

When we turned to the query about the effect of the conflicts on the lawyers' most recent encounters, we found that the evidence was more equivocal. Affirmative answers outnumbered negative answers for only three conflicts. For three other conflicts, the numbers were almost the same.

But what sorts of effects were the lawyers referring to? And how closely did their experiences correspond to the Federal Courts Study Committee's concept of harm to multicircuit actors? 'To find out, we looked at the explanatory comments that accompanied the affirmative responses. The most frequent comment was that the lawyer recommended a more conservative course of action. One attorney elaborated upon this point:

As a practitioner who mainly counsels large corporations operating nationally, which are only rarely involved in antitrust cases, staying out of court is a major goal. The existence of intercircuit conflicts, like any other uncertainty in antitrust law, results in counseling advice based on conservative assumptions (i.e., that the most restrictive view will be followed). Obviously, this most conservative advice is not always followed by clients. However, when it is not followed and a more aggressive position is taken, it is done so conscious that the risk is [increased].

\footnotetext{
${ }^{122}$ Among the 71 antitrust comments in response to the question on counseling, 41 focused, explicitly or implicitly, on counseling in the context of primary conduct. Twentyfour responses were ambiguous as to context. Only five comments clearly dealt with claims or litigation.

${ }^{123}$ Of the 147 maritime comments in response to the question on counseling, only 12 were concerned with primary conduct; 99 referred to particular claims or incidents. The reınainder were ambiguous as to context.
} 
This theme was sounded in more than one-third of the explanatory comments offered by the antitrust lawyers in response to the counseling question. For example:

- "Advised client (a likely target defendant) that conflict created ambiguity and therefore risk. Led to more conservative conduct." (Conflict on uniqueness of tying product.)

- 'Had client use the higher 'total cost' number, as a safety net." (Conflict on proper measure of cost in predatory pricing. $)^{124}$

Other antitrust lawyers referred to "recognizable" or "excessive" risk (without explicitly saying that they had recommended a more conservative course of action) or said only that the conflict had made it more difficult to give definitive advice.

These comments reinforce the conclusion that, in the realm of antitrust, conflicts sometimes added to the difficulty of counseling clients on pricing policies or other matters arising in the conduct of business. What is not so clear is how frequently this occurred in absolute terms. The survey responses encompass more than 150 encounters with the eight core conflicts. Within this group, negative answers to the question about effect on counseling slightly outnumbered the positive.

On this particular point, however, we need not rely entirely on lawyers' after-the-fact descriptions; we also have some direct contemporaneous evidence of the conduct of a sophisticated multicircuit actor. The area of law most likely to be analyzed on a circuitby-circuit basis is predatory pricing. ${ }^{125}$ As it happens, we have access to extensive internal documentation of an aggressive pricing campaign by a major national firm. This comes about because the firm, the Brown \& Williamson Tobacco Corporation, was sued by a competitor, Liggett, in a case that ultimately went to the Supreme Court. ${ }^{126}$ In response to Liggett's discovery requests,

\footnotetext{
${ }^{124}$ Similar comments were made in interviews. One antitrust lawyer, discussing the conflict over the "sham" exception to Noerr immunity, recalled that he once gave a client very conservative advice "by asking the client to put himself in a witness box and see if the practice could be defended to a jury."

${ }^{125}$ See, for example, 3 Julian O. Von Kalinowski et al, Antitrust Laws \& Trade Regulation $\$ 21.03[3]$ (1993) (case law sumınaries for individual circuits).

${ }^{126}$ Brooke Group Ltd. v Brown \& Williamson Tobacco Corp., 509 US 209 (1993). "Brooke Group" is the new corporate name of the entity formerly known as the Liggett Group,
} 
Brown \& Williamson disclosed internal documents that were described by the district judge as "more voluminous and detailed than [in] any other reported decision." 127 These documents indicate that the Brown \& Williamson executives did consider "legal risks" in formulating their pricing strategy. ${ }^{128}$ But nothing in the memoranda even hints that the company considered anything other than a national approach. ${ }^{129}$ If, in this setting, intercircuit differences did not affect planning by a national corporation, one must wonder how salient the phenomenon really is even for wellcounseled multicircuit actors.

In maritime law, the frequency question yielded mixed results. For four of the conflicts, responses at the high end of the scale outnumbered those at the low end. For the other four, the pattern was reversed. But when we move to the question about the respondents' most recent encounters with the selected conflicts, we find that affirmative answers outnumbered negative answers for all but two of the core conflicts.

Once again, the explanatory comments shed light on the nature of the experiences that underlay these responses. Like their antitrust counterparts, maritime lawyers often spoke of hedging their advice, but, other than that, the pattern of responses was quite different. Only two participants said that they had counseled a

and practitioners often refer to the case as Liggett. In some sources the petitioner's new name is spelled as "Brook."

${ }^{127}$ Liggett Group Inc. $v$ Brown \& Williamson Tobacco Corp., 748 F Supp 344, 354 (MD NC 1990), aff'd, 964 F2d 335 (4th Cir 1992), aff'd, 509 US 209 (I993).

${ }^{128}$ In an internal memorandum that "provide[d] the pros and cons for two potential Brown \& Williamson price offerings," the writer listed "[p]ossibly greater legal risks" "as one of the 'Cons' of the 'Black and White' and Private Label Offerings" approach. Joint Appendix at 105, Brooke Group Ltd. v Brown \& Williamson Tobacco Corp., 509 US 209 (1993) (No 92-466). A later version of the document referred simply to "Legal risks." Id at 113.

${ }^{129}$ The portion of the "pros and cons" document that elaborates on the "legal risks" is not included in the Supreme Court record. However, the complete document is reproduced in the record on appeal in the Fourth Circuit. The discussion of legal risks is only one sentence in length, and it may not even refer to predatory pricing. See Joint Appendix at A-1707, Liggett Group Inc. v Brown \& Williamson Tobacco Corp., 964 F2d 335 (4th Cir 1992) (Nos 90-1851, 90-1854) ("To the extent that Brown \& Williamson's offering will be sinnilar to $L \& M$, we risk legal actions by that company."). One might surmise that full discussion of the point was contained in material that was withheld from discovery on the grounds of privilege. However, the record in Liggett included "several dozen documents" which Brown \& Williamson claimed were subject to attorney-client privilege or work-product protection, but which were "inadvertently" produced during discovery. See Liggett Group Inc. v Brown \& Williamson Tobacco Corp., 116 FRD 205, 207 (MD NC 1986) (denying motion to "recall" documents). In any event, I found no further references to the prospect of "legal risks" in any of the later memoranda. 
more conservative approach to primary activity. None referred to the risks engendered by a proposed course of conduct. Rather, the maritime lawyers described their handling of claims triggered by accidents that had already occurred. Some said that the conflicts had affected litigation strategy. More often, the lawyers reported that the conflict had influenced their evaluation of a claim or the amount to be paid in settlement. ${ }^{130}$

The comments by the maritime lawyers thus indicate that the conflicts generally had little impact in matters involving the conduct of business. However, the conflicts did sometimes contribute to the difficulty of advising clients when incidents occurred that might be the basis for a legal claim. Further, and in contrast to the antitrust survey, affirmative answers represented a majority of the encounters reported by the participants in the context of counseling. Yet, as noted at the outset, the responses to the frequency question did not bespeak a phenomenon of significant proportions.

To make sense of the data, we must look at the conflicts separately. The key fact is that more than two-thirds of the encounters that elicited affirmative responses to the counseling question were generated by three conflicts-those involving seaman status under the Jones Act, punitive damages for injuries to seamen, and recovery for economic loss. The survey thus provides evidence that those conflicts did make counseling more difficult, albeit not in the context of primary activity. As for the other conflicts, the impact appears to have been relatively minor.

The legal context of the conflicts. As already noted, it will often be difficult to distinguish between the consequences flowing from the existence of a conflict and those generated by other sources of uncertainty in the law. To shed light on this point, we invited the survey respondents to consider the conflict issues in their larger context. Specifically, the lawyers were asked to choose one of five possible characterizations for each of the selected conflicts:

1. The conflict is a major source of uncertainty in an area of law that would otherwise be clear.

\footnotetext{
${ }^{130}$ The difference between the antitrust and maritime responses probably reflects the differcnt characters of the two kinds of practice: maritime practice is far more litigationoriented than is antitrust. In statistical year 1994, more than 5,000 maritime cases were filed in the federal courts alone. Antitrust cases-which are exclusively within the jurisdiction of the fedcral courts-numbered fewer than 700. Director of the Administrative Office of United States Courts, Annual Report, table C-2A (1994).
} 
2. The conflict is a major source of uncertainty, but is only one element of an area of law that is lacking in definitive rules.

3. The conflict is a minor source of uncertainty in an area of law that is otherwise clear.

4. The conflict is a minor source of uncertainty in an area of law that is lacking in definitive rules.

5 . The conflict issue described does not create any serious legal uncertainty.

In antitrust, the survey evidence indicates that the conflicts generally did not play a central role in creating uncertainty. Only one conflict was viewed as "a major source of uncertainty in an area of law that would otherwise be clear" by more than 25 percent of the respondents; this was the conflict on the proper measure of cost for a predatory pricing claim. Six of the eight core conflicts were characterized by a substantial majority of the respondents as arising in areas of law that were lacking in definitive rules, not areas of law that were otherwise clear. From this we may infer that resolution of the conflicts would not have significantly diminished whatever effects the conflicts had on lawyers' ability to advise clients and conduct litigation.

The pattern of responses in maritime law was quite different. For all but one of the eight core conflicts, a majority of the lawyers said that the area of law would have been clear if it were not for the conflict. Five of the conflicts were viewed as major sources of uncertainty by two-thirds or more of those discussing the particular issue. Included among these were the three conflicts that appear to have made counseling more difficult; ${ }^{131}$ the other two were the conflicts on the fire defense and the effect of deviation on limitation of liability under COGSA.

\section{SUMMARY AND EVALUATION}

The object of the field research was to determine whether conflicts that had the potential for affecting the work of lawyers actually did so. The findings suggest several conclusions.

The most clear-cut finding is that lawyers seldom file suit in

\footnotetext{
131 These were the conflicts involving seaman status under the Jones Act, punitive damages for injuries to seamen, and recovery for economic loss.
} 
one circuit rather than another in order to take advantage of favorable circuit law or to avoid an unfavorable precedent. Thus, the Federal Courts Study Committee's concern that conflicts "encourage forum shopping among circuits" appears to be misplaced. Further, to the extent that forum shopping signals unfairness or harm to multicircuit actors, those consequences too would not materialize.

This conclusion comports with what we know of litigation practice generally. As Professor Edward A. Purcell has pointed out, litigating in a distant forum can involve "substantial . . . costs, risks, delays, and uncertainties." 132 The disincentives to filing suit in any place but the client's home forum (and that of counsel) are numerous and strong. ${ }^{133}$ To overcome these disincentives, a lawyer would have to be convinced, not only that some other circuit's law was substantially more favorable, but that the difference would remain in existence long enough to control the disposition or settlement of the case. That will not happen very often.

Beyond this, the effect of conflicts appears to vary from one area of practice to another. The survey responses indicate that conflicts in the field of antitrust had their greatest impact when lawyers were counseling clients about the possible legal ramifications of a proposed course of conduct. In maritime law, conflicts came into the picture when lawyers were considering litigation or settlement of claims for incidents that had already occurred.

The most difficult task is to determine how often these situations occurred and how serious the consequences were. We do have some clues. To begin with, the number of conflicts that merited full-scale field research is quite small. In four major areas of federal practice, the residue from five Supreme Court Terms after the initial lawyer interviews consisted of only 30 conflicts. Even if every one of those conflicts proved to be a frequent impediment to efficient litigation or effective counseling, I doubt that we would view this as a major problem in the legal system.

In fact, the research suggests a more limited impact. This conclusion emerges most clearly in the survey participants' descrip-

${ }^{132}$ Edward A. Purcell, Jr., Geograpby as a Litigation Weapon: Consumers, Forum-Selection Clanses, and the Rehnquist Court, 40 UCLA L Rev 423, 445 (1992).

${ }^{133}$ See id at 445-49 (analyzing "deterrent effects of geography"); see also Michael E. Solimine, The Quiet Revolution in Personal furisdiction, 73 Tulane L Rev 1, 56 (1998). 
tions of their most recent encounters with the core conflicts. We asked separately whether the conflicts affected litigation and whether they affected counseling. In antitrust, only three conflicts elicited more "yes" than "no" answers to either question. In the maritime survey, six conflicts fit this pattern; however, for all but one of those, at least one-third of the lawyers reported that the conflict had had no effect.

It is also important to note that what the maritime numbers represent, as revealed by the explanatory comments, is something quite distant from the concerns articulated by the Federal Courts Study Committee. Of particular relevance, in elaborating on the concept of "harm to multi-circuit actors," the Study Committee spoke of "adverse consequences [that] are felt in the planning and execution of business transactions, or their avoidance." 134 Although the maritime lawyers' comments vary widely in their specificity, what stands out is that very few of them refer to the planning and execution of business transactions at all. Rather, as noted earlier, they deal with liability for incidents that had already occurred.

Why do conflicts that have the potential for affecting the selection of the forum or interfering with planning by multicircuit actors so seldom do so? Drawing on the interviews and practice materials, as well as the more general comments from survey participants, I have identified five factors that tended to diminish the impact of the Study Group conflicts on the work of lawyers.

First, few of the conflicts involved rule choices that were likely to control outcomes. Sometimes the law in one or both circuits contained elements of indeterminacy. Often the conflict issue was only one part of a network of rules that would be brought to bear in advising clients on primary conduct or the possibility of litigation. Seldom would lawyers conclude that the point on which the circuits differed would determine whether a transaction was lawful or a lawsuit winnable.

Second, as hypothesized earlier, lawyers generally view federal decisions as constituting a single body of law. Indeed, practice materials sometimes described the "conflict" cases in a way that signaled harmony rather than inconsistency.

Third, experienced lawyers give less weight to individual prece-

${ }^{134}$ Federal Courts Study Committee, Tentative Recommendations for Public Comment (Dec 22, 1989) at 119. 
dents and specific holdings than a doctrinally focused perspective might suggest. ${ }^{135}$ They are well aware of the techniques that enable a court of appeals panel to distinguish prior cases and of the differences in judicial philosophy that may lead a panel to do so. ${ }^{136}$ They are cognizant, too, of the hierarchical structure that allows the Supreme Court to overrule circuit law. Of particular importance, if lawyers perceive a trend or pattern in the actions and rationales of courts nationwide, they will often discount decisions that appear to be aberrations. ${ }^{137}$

Fourth, federal appellate decisions are only one source of the legal rules that lawyers consider in litigation and counseling. In many situations, rules emanating from other sources may be given more weight. For antitrust lawyers, Department of Justice and Federal Trade Commission guidelines may set the bounds of permissible activity. For maritime lawyers, nonpreempted state law may offer support for particular claims irrespective of federal law. ${ }^{138}$

${ }^{135}$ This theme was sounded by many of the practitioners I interviewed; it can also be seen in a number of published works. For example, an overview of antitrust counseling by a practicing attorney acknowledges the existence of unresolved conflicts, but goes on to say that "perhaps the only way ... to counsel clients in the antitrust area is to ignore ... the results of specific cases and to concentrate instead on five basic factors that have historically been involved in establishing liability under the antitrust laws." Donald E. Knebel, Antitrust Counseling: The Five Factors of Antitrust Liability, 9 J Corp L 359, 364 (1984).

${ }^{136}$ As one participant in the maritime survey put it, "While precedent is very important, hope does spring eternal. Bright minds and judicial identity render precedent often secondary." Another participant was more acerbic: "The author of a panel opinion can justify almost any result by disregarding certain established fact, creating evidence, or ignoring established precedent."

${ }^{137}$ As one antitrust lawyer said in responding to our survey, "I find I can advise comfortably as long as I believe any court will continue to strive for decisions that make sense ftom an economic perspective. In general, 'bad' precedent for my clients is usually distinguisbable, and this is a better climate for antitrust than if apparent conflicts were resolved too bastily." A prominent example of an aberrational decision is Lessig $v$ Tidewater Oil Co., 327 F2d 459 (9th Cir 1964), in which the Ninth Circuit adopted a relatively lenient standard for attempted monopolization under Section 2 of the Sherman Act. One of the lawyers I interviewed said, "When Lessig was the law I ignored it because I thought it was bad law and wasn't likely to survive long." Other lawyers spoke in a similar vein. Although Lessig survived longer than might have been expected, it has now been overruled. See note 140 and accompanying text.

${ }^{138}$ State law plays a role in antitrust counseling as well. One survey participant wrote, "In counseling, it is often difficult to factor in how various state laws will affect the outcome if the matter were litigated. The area of distributor and dealer termination is particularly tricky due to [the] interplay of contract, tort, dealer laws and federal laws on antitrust. In some states like Wisconsin, it is virtually impossible to terminate a dealer due to the Wisconsin Fair Dealership Law even where poor performance is habitual. Even though [Supreme Court decisions bave] clarified the federal law, the state laws have kept things very muddy in the dealer termination area." 
Finally, legal rules of any kind are only one of the elements that lawyers consider in counseling and litigation, and they are not necessarily the most important. Especially where ongoing relationships are involved, those who operate within the framework of the law may not insist on enforcing the full measure of their legal rights.

\section{E. THE STUDY GROUP CONFLICTS AND THE SUPREME COURT}

The picture that emerges from the field research is very different from the one suggested by the Federal Courts Study Committee report. Seldom do unresolved intercircuit conflicts lead to forum shopping. Harm to multicircuit actors is somewhat more common, but still infrequent. What we do find is uncertainty that adds to the difficulty lawyers have in counseling clients.

There will be differences of opinion about how serious a problem this kind of uncertainty presents. Before we can evaluate it, however, we must consider one additional factor: the effect of intervening decisions by the Supreme Court. These decisions can be divided into two groups: those that resolved Study Group conflicts, and those that addressed closely related issues.

Of the 30 conflicts that remained in the field research program after the initial lawyer interviews, six have been resolved. ${ }^{139}$ These include two conflicts in antitrust, two in maritime law, and two on ERISA issues.

In antitrust, the Court rejected the Ninth Circuit's Lessig rule and established uniformity on the elements of a claim of attempted monopolization. ${ }^{140}$ The Court also clarified the "sham" exception to Noerr immunity, thus resolving another long-simmering conflict. ${ }^{141}$

The two maritime law decisions also involved issues that had

\footnotetext{
${ }^{139}$ In the explanatory materials we sent to the survey participants, we acknowledged that some of the conflicts had been resolved. We asked the lawyers to describe their experiences as of the time certiorari was denied.

${ }^{140}$ Spectrum Sports, Inc. v McQuillan, 506 US 447 (I993). The issue was presented to the Supreme Court in Mobil Oil Corp. v Blanton, 47I US 1007 (1986) (White, J, dissenting from denial of certiorari) (Phase II case; RN 806).

${ }^{141}$ See Professional Real Estate Investors, Inc. v Columbia Pictures Indus., 508 US 49 (1993). Among the cases cited by the Supreme Court as illustrating the "inconsistent and contradictory" definitions adopted by the courts of appeals was Soutb Dakota v Kansas City So. Indus., Inc., 880 F2d 40 (8th Cir 1989), cert denied, 493 US 1023 (1990) (RN 450).
} 
been the subject of extensive litigation in the lower courts. The Court resolved the conflict over the validity of an "aid in navigation" requirement for seaman status under the Jones Act. ${ }^{142}$ More recently, the Court clarified the circumstances under which a shipowner can be held liable under the LHWCA for injuries arising out of defective stowage. ${ }^{143}$

In the realm of ERISA, the Court took up two issues within a year of the denial of certiorari in the Study Group cases. One decision resolved the conflict over coverage of insurance agents. ${ }^{144}$ The second dealt with the interplay of ERISA and the bankruptcy code. ${ }^{145}$ Both were described as important by the lawyers whom I interviewed.

In addition to these decisions, Supreme Court rulings on related issues have cast five of the Study Group conflicts in a new light. This phenomenon was particularly significant in antitrust.

The Study Group included two conflicts on the elements of a predatory pricing claim under Section 2 of the Sherman Act. One involved the proper measure of cost; the other dealt with the role of intent. The Supreme Court has not resolved either of these issues; however, in Brooke Group Ltd. v Brown \& Williamson Tobacco Corp. (the Liggett case), ${ }^{146}$ the Court made clear that a plaintiff cannot prevail on a predatory pricing claim without showing a dangerous probability that the defendant would recoup its investment in below-cost prices. ${ }^{147}$ This recoupment requirement makes the cost and intent issues largely irrelevant in most cases. Indeed, some prominent attorneys view Liggett as having delivered the coup de grace to all predatory pricing claims. ${ }^{148}$

Another decision of the same Term, Hartford Fire Insurance Co.

${ }^{142}$ McDermott Int'l, Inc. v Wilander, 498 US 337 (1991).

${ }^{143}$ Howvlett v Birkdale Shipping Co., 512 US 92 (1994).

${ }^{144}$ Nationwide Mut. Ins. Co. v Darden, 503 US 318 (1992).

${ }^{145}$ Patterson v Shumate, 504 US 753 (1992).

${ }^{146} 509$ US 209 (1993), discussed in text accompanying notes 126-29.

${ }^{147}$ Brooke Group, 509 US at 224.

${ }^{148}$ This view has been expressed by both plaintiffs' and defendants' lawyers. See, for example, Kenneth L. Glazer, Predatory Pricing and Beyond: Life After Brooke Group, 62 Antitrust L J 605, 605 (1994) (article by counsel for plaintiffs in Liggett case); Mark E. Weber, Developments: Practical Effects of Liggett on Predatory Pricing Litigation, Antitrust (Fall 1993) at 38 (article by counsel for defendants in American Airlines antitrust suit). The point was also made by several of the lawyers I interviewed. 
$v$ California, ${ }^{149}$ addressed the extraterritorial reach of the antitrust laws. The problem of extraterritoriality gave rise to one of the Study Group conflicts; ${ }^{150}$ however, the Court virtually ignored the case that was the focus of the conflict and, instead, decided Hartford Fire on narrow grounds. ${ }^{151}$ But the conflict had never played a central role in litigation over extraterritoriality; ${ }^{152}$ thus, in that respect, the Court left the law largely where it had been.

The issue of dealer termination as a per se violation of Section 1 of the Sherman Act, which the Court declined to consider in the 1984 Term, presents a more complex picture. ${ }^{153}$ The 1988 decision in Business Electronics Corp. $v$ Sharp Electronics Corp. ${ }^{154}$ went a great distance toward rejecting the application of a per se rule, to the point where one survey participant could describe the issue as "largely moot." Nevertheless, the conflict was selected by more lawyers for detailed discussion than any other in the antitrust survey. Moreover, most of the lawyers who offered explanatory comments gave no indication that they viewed the issue as defunct. ${ }^{155}$

At first blush, it seems rather odd to find so much concern about an issue that had been resolved, at some level of generality, several years before the survey was conducted. A partial explanation may be that some lawyers believe that the Third Circuit, whose rule was rejected in Business Electronics, has continued to march to its own drummer. ${ }^{156}$ Whether or not that characterization is persua-

149509 US 764 (1993).

${ }^{150}$ The issue was presented to the Supreme Court in Timberlane Lumber Co. $v$ Bank of America, 749 F2d 1378 (9th Cir 1984), cert denied, 472 US 1032 (1985) (Phase II case; RN 844).

151 See Andreas F. Lowenfeld, Conflict, Balancing of Interests, and the Exercise of 7urisdiction to Prescribe: Reflections on the Insurance Antitrust Case, 89 Am J Intl L 42, 45 (1995).

152 See Hellman, By Precedent Unbound at 788 (cited in note 8).

${ }^{153}$ The Study Group case was Malley-Duff \& Associates, Inc. $v$ Crown Life Insurance Co., 734 F2d 133 (3d Cir), cert denied as Agency Holding Corp. $v$ Malley-Duff \& Associates, Inc., 469 US 1072 (1984) (Phase II case; RN 766).

154485 US 717 (1988).

${ }^{155}$ As a general matter, I do not think the lawyers adhered strictly to our request that they discuss their experience with the conflicts as of the time certiorari was denied. Perhaps this was just as well.

${ }^{156}$ Among the cases cited in support of this view is Alvord-Polk, Inc. $v$ F. Schumacher do Co., 37 F3d 996 (3d Cir 1994), cert denied, 514 US 1063 (1995). One CLE author described Alvord-Polk as "completely contrary to the trend indicated by Supreme Court opinions." Alan H. Silberman, Vertical Price, Customer and Territorial Limitations, in 36th Annual Antitrust Institute (Practicing Law Institute, 1995), vol 1 at 727. 
sive, the lawyers' responses suggest two other conclusions. First, the conflict that the survey respondents were discussing is not the same conflict that the Supreme Court declined to resolve in the 1984 Term. The issue may be framed in similar language, but beneath that similarity lie important differences in the legal propositions that are taken as given and those that are viewed as litigable. Second, Supreme Court decisions that resolve conflicts may end up reshaping lines of argument or advice rather than placing an issue outside the range of uncertainty.

Maritime law offers an example of what might be regarded as a correlative phenomenon. The conflict is the one over the availability of punitive damages for injuries suffered by seamen. ${ }^{157}$ The Supreme Court has never addressed that issue; however, in Miles $v$ Apex Marine Corp., ${ }^{158}$ the Court held that the damages recoverable in a general maritime cause of action for the wrongful death of a seaman do not include either loss of society or lost future earnings. Although Miles said nothing about the conflict issue, ${ }^{159}$ every court of appeals to consider the question has now concluded that, under the analysis in Miles, punitive damages may not be recovered for injuries suffered by seamen. ${ }^{160}$ These courts include the Fifth Circuit, whose decision in Complaint of Merry Shipping ${ }^{161}$ was the leading pre-Miles authority supporting the availability of punitive damages. ${ }^{162}$ Moreover, the Louisiana appellate court, whose position was cited by several survey respondents as contrary to that of the Fifth Circuit, ${ }^{163}$ has also overruled its precedent and held that punitive damages are unavailable. ${ }^{164}$ Thus, it seems un-

${ }^{157}$ The issue was presented to the Court in the 1989 Term. See McMonagle $v$ Northeast Women's Center, Inc., 493 US 901, 902 (1989) (White, J, dissenting from denial of certiorari) (citing Kidd $v$ F/V St. Patrick, 493 US 871 (1989), denying cert to 816 F2d 1345 (9th Cir 1987) (RN 101)).

158498 US 19 (1990).

${ }^{159}$ The only mention of punitive damages comes in the Court's statement of the facts, which notes that the district court granted the defendant's motion to strike the claim for punitive damages. See id at 22.

${ }^{160}$ See, for example, Horsley v Mobil Oil Corp., 15 F3d 200, 203 (1st Cir 1994).

${ }^{161} 650 \mathrm{~F} 2 \mathrm{~d} 622$ (1981).

${ }^{162}$ In Guevara v Maritime Overseas Corp., 59 F3d 1496, 1507 (5th Cir 1995) (en banc), the court said, "After Miles, it is clear that Merry Shipping has been effectively overruled."

${ }^{163}$ One lawyer said, "Plaintiffs routinely file in state court in Louisiana, where Miles $v$ Apex has been interpreted in a more limited fashion."

${ }^{164}$ See Bridgett $v$ Odeco, Inc., 646 So2d 1249 (La App 1994). The court noted that the "anoinalous interpretations of Miles" in prior Louisiana cases served "no purpose other than 
likely that lawyers in the future will continue to experience the difficulties reported by so many survey respondents in counseling on this issue, even though no nationally binding precedent explicitly resolves it. ${ }^{165}$

\section{F. RECAPITULATION}

Of the 30 conflicts that remained for field research after the initial attorney interviews, 10 have been significantly affected by intervening Supreme Court decisions. Six or seven have been resolved by decisions squarely addressing the conflict issue. ${ }^{166}$ One conflict has been eliminated by circuit overruling in light of a Supreme Court decision on a related issue. ${ }^{167}$ Two have been made largely irrelevant by the Court's endorsement of a high hurdle for the underlying cause of action. ${ }^{168}$ In short, 10 of the conflicts no longer exist in anything resembling the form that they took at the time the Court denied review. Included in this group are several of the conflicts that most often affected the work of the lawyers who participated in the survey. ${ }^{169}$

At the least, this history cautions against interpreting the survey responses as evidence that unresolved intercircuit conflicts constitute a problem of major proportions in the practice of law. But it also suggests a broader point about conflicts, one that is best discussed as part of an overall assessment of the implications of the research.

\section{IMPlications}

One mystery has always attended the debate over "national appellate capacity" generally and the "problem" of unresolved

to encourage plaintiffs to engineer arguments in favor of invoking jurisdiction in [Louisiana] courts." Id at 1254. Bridgett was reaffirmed in Brodtmann v Duke, 708 So2d 447, 452-53 (La App 1998).

${ }^{165}$ Pockets of uncertainty may remain on related issues. See, for example, CEH, Inc. $v$ F/V Seafarer, 70 F3d 694, 701-02 (1st Cir 1995) (allowing punitive damages "for reckless or willful destruction of property"; distinguishing cases involving personal injuries to seamen).

${ }^{166}$ The debatable case is Business Electronics.

${ }^{167}$ This is the conflict on the availability of punitive damages for injuries to seamen.

${ }^{168}$ These are the conflicts on predatory pricing in antitrust.

${ }^{169}$ The major exception is the conflict over recovery for economic loss in admiralty. See Hellman, By Precedent Unbound at 791 (cited in note 8). 
conflicts in particular. If the Supreme Court has largely given up on maintaining uniformity in the federal system ${ }^{170}$ and conflicts are accumulating faster than they are being resolved, ${ }^{171}$ why is there no outcry from the rank-and-file of the bench and bar? One possible explanation, favored by some academics, is that lawyers prefer a regime of uncertainty because it "generates a huge business" for them and their firms. ${ }^{172}$ But even if that is true for some litigationoriented practitioners, surely it does not explain the indifference of the many lawyers who engage primarily in counseling or of the busy trial judges confronted with motions and pleadings that require immediate decision.

The answer suggested by this study is that the problem of unresolved conflicts exists only if you look for it-and look for it in a certain way. If you concentrate your attention on individual court of appeals decisions that create conflicts and on individual denials of certiorari in conflict cases, you will see "a judicial "darkling plain' where ignorant armies [clash] by night." ${ }^{173}$ But if you look at the conflict issues over a period of time and in context, you will find, if not certitude, a landscape in which courts build upon and reexamine one another's decisions in the untidy but constructive tradition of the common law.

The field research suggests a broader point. The very language that we use to talk about conflicts may convey a misleading picture of what is going on. We say that an "issue" gives rise to a "conflict" that the Supreme Court "resolves" (or does not "resolve"). This language implies that the dimensions of the "issue" remain unchanged from the first decision through consideration by two or more courts of appeals and ultimate resolution by the Supreme Court. The implication is probably correct when the issue is binary and discrete, like the one involved in United States $v$ Cartwright. ${ }^{174}$

\footnotetext{
${ }^{170}$ See Kenneth W. Starr, The Supreme Court and the Federal fudicial System, 42 Case Western L Rev 1209, 1212 (1992).

${ }^{171}$ See note 10 and accompanying text.

${ }^{172}$ See Panel Discussion I, 38 SC L Rev 463, 484 (1987) (remarks of Prof. Paul M. Bator).

${ }^{173}$ See Northern Pipeline Construction Co. v Marathon Pipe Line Co., 458 US 50, 91 (Rehnquist, J, concurring). Justice Rehnquist was of course quoting Matthew Arnold's "Dover Beach": "[F]or the world . . / / Hath really neither joy, nor love, nor light,/ Nor certitude, nor peace, nor help for pain;/ And we are here as on a darkling plain/Swept with confused alarms of struggle and flight,/ Where ignorant armies clash by night."

${ }^{174} 411$ US 546 (1973). The question in Cartwright was whether mutual fund shares in a decedent's estate were to be valued at the bid price or the asked price. No one argued that
} 
For other issues, however, the reality will not be so straightforward. Judges and lawyers may continue to frame the issue in the same words, but beneath the verbal identity may lie important differences in the propositions that are accepted as part of the legal landscape and those that are viewed as litigable. Similarly, when the Supreme Court does intervene, its decision may end up reshaping the framework for litigation and counseling about an issue rather than closing a chapter in the particular area of the law. ${ }^{175}$

The conflict on dealer termination under Section 1 of the Sherman Act provides a good example. ${ }^{176}$ What was the "issue" that gave rise to the conflict? Did the Supreme Court resolve it in the Business Electronics case? If so, why is there so much continued uncertainty about the law governing the termination of price-cutting dealers and distributors? If not, how could the Supreme Court come so close and not resolve a matter of so much importance to a large segment of the economy?

Perhaps these are the wrong questions. Perhaps we should simply recognize that the further we move from Cartwright-type conflicts, the more likely it is that a Supreme Court decision will recast the framework for litigation and counseling about an issue rather than relegate the issue to the realm of the defunct. By the same token, the Court's failure to resolve such conflicts will add only marginally to the uncertainty that is inherent in our system of precedent.

In this light, there is a certain irony in Justice Scalia's comments about the cases in which the Supreme Court denied review over Justice White's dissent. Justice Scalia said, "If it's really an important issue, it's going to be back . . . ." "177 But when "it" comes

there were any other possibilities. The question thus involved a choice hetween two perfected rules-rules that required for their application no more than a finding of historical fact. The rules were self-contained in operation and dispositive in all disputes in which the issue arose. See Hellman, By Precedent Unbound at 760-61 (cited in note 8).

175 This pattern can be viewed as a departure from the traditional model of lawmaking by appellate courts. In that model, the law "works itself pure from case to case." Graham Hughes, Are 7ustices 7ust? New York Review of Books (Nov 19, 1981) at 41, 42 (quoting Lord Mansfield on the common law); see Hellman, 23 Ariz St L J at 917 and n 13 (cited in note 78). In the situation described in the text, the law never "works itself pure"; rather, uncertain boundaries and gray areas characterize the legal landscape as long the issue, in some form, remains alive. In future work I shall explore the origins and implications of this development.

${ }^{176}$ See text accompanying notes 153-56.

${ }^{177}$ See text accompanying note 34 . 
back, it may not be quite the same issue. And the Court may deny review once again, implicitly agreeing with Justice Brandeis that sometimes "the most important thing we do is not doing."

${ }^{178}$ Conversations Between L.D.B. and F.F. [Louis D. Brandeis and Felix Frankfurter], Typescript at 15 (conversation of June 23, 1923), in The Louis Dembitz Brandeis Papers, Part II: United States Supreme Court, October Terms, 1932-1938, Reel 33, Frame 464 (University Publications of America microfilm collection). See also Alexander M. Bickel, The Unpublished Opinions of Mr. Fustice Brandeis 17 (Chicago, 1957) (quoting Brandeis-Frankfurter Conversations). Bickel does not give the context of the remark. As recorded in Frankfurter's notes, Brandeis was talking about his colleagues' indifference to issues of federal jurisdiction. Justice Holmes, he said, "likes to decide cases where interesting questions are raised." But "Holmes is beginning to learn-intellectually he is beginning to appreciate our responsibility, though not emotionally. I tell him, 'the most important thing we do is not doing.' " 